\title{
Upper crust reworking during gravitational collapse: the Bembibre-Pico Sacro detachment system (NW Iberia)
}

\author{
JUAN G@́MEZ BARREIR 1* J J SÉ R. MARTÍNEZ CATALÁN², RUBÉN DÍEZ FERNÁNDEZ², \\ RICARD॰ ARENAS ${ }^{1} \&$ FL@RENTIN• DÍAZ GARCÍA ${ }^{3} \dagger$ \\ ${ }^{1}$ Departamento de Petrología y Geoquímica-Instituto de Geología Económica CSIC, Universidad Complutense, 28040. \\ Madrid, Spain \\ ${ }^{2}$ Departamento de Geología, Universidad de Salamanca, 37008 Salamanca, Spain \\ ${ }^{3}$ Departamento de Geología, Universidad de Oviedo, 33005 Oviedo, Spain \\ †Deceased \\ *Corresponding author (e-mail: jugb@usal.es)
}

\begin{abstract}
The kinematics of the basal allochthon in the SW of the Órdenes Complex is analysed to constraint its evolution during collisional and postcollisional stages of the Variscan orogeny. Two distinct sequences have been identified in the basal allochthon of this sector: the upper and lower sequences, in close correlation with the subdivision of the basal allochthon in the Malpica-Tui Complex. Three main tectonic episodes have been established in the basal allochthon: a high-pressure event related to continental subuction, a mesozonal event of regional exhumation by thrusting and recumbent folding, and a regional-scale extensional episode that resulted in the development of the Bembibre-Pico Sacro detachment system. The Bembibre-Pico Sacro system rejuvenated pre-existing shear zones, whose wealmess favoured the nucleation of the detachments. Shear zones associated with the detachments overprinted the previous tectonic fabrics under conditions ranging from lower amphibolite to greenschist facies, and with heterogeneously distributed ductile to brittle deformation. The detachment system is coeval with late orogenic collapse and widespread magmatism, and represents its upper crustal expression. It correlates with mid- and lower crustal flow and the development of gneiss domes at depth in such a way that the basal allochthon can be considered a rheological boundary between the more rigid allochthonous sequences above and the more viscous Schistose Domain and autochthon below.
\end{abstract}

Continental lithosphere is characterized by cumulative growth during orogenic periods. Long-term persistence of the structural architecture, particularly shear zones and faults, and the overlapping of fabrics, metamorphic events and magmatic episodes, determines the way in which the lithosphere reacts to every new tectonothermal event (Neil \& Houseman 1997; Holdsworth et al. 2001 ; Houseman \& Molnar 2001). The existence of mechanical discontinuities and the variation of lithospheric thermal state seem to be essential controls that potentially shape subsequent episodes (Butler et al. 1997; Holdsworth et al. 1997). Regional studies in collisional scenarios on tectonic renewal of both discrete smuctures (reactivation) and, at a larger scale, lithospheric or crustal volumes (reworking) are critical to understanding the rheological behaviour of an orogenic belt with time.

In this context, the geodynamic evolution of the basal allochthon in the NW Iberian Massif is examined. The basal allochthonous units are key pieces of the intricate and long-standing Variscan orogenic puzzle. They represent the outermost edge of the Gondwana supercontinent, having undergone distinct tectonothermal events related to the continental subduction $\left(\boldsymbol{D}_{1}\right)$ and subsequent collisional deformation $\left(\mathbf{D}_{2}\right)$ during the Variscan orogeny. However, their role during late orogenic extensional collapse $\left(\mathbf{D}_{3}\right)$ remains obscure. Here we focus on this third event (D), during which regional-scale extensional detachments partially rejuvenated previous structures and dominated the deformation of the basal allochthon.

\section{Geological context}

The NW Iberian Massif includes an autochthonous realm formed by metamorphic rocks ranging from very low grade to catazonal, and by plutonic rocks. Allochthonous units occur above the Iberian autochthon, and represent the remnants of a huge and structurally complex nappe stack formed by terranes with different degrees of exoticism. Among the five existing allochthonous complexes, Cabo Ortegal, Ordenes, Malpica Tui, in Spain, and Morais and Bragnaça, in Portugal, the Ordenes Complex is the largest (Fig. 1; Martínez Catalán et al. 2009) and includes the full sequence of allochthonous units recognized.

The allochthonous units are grouped according to their origin and the structural position they occupy in the nappe pile. They include pieces of a Cambro-Ordovician ensialic island arc on top (upper allochthon, Andonaegui et al. 2002; Santos et al. 2002; Abati et al. 2003; Castiñeiras 2005; Gómez Barreiro et al. 2006; Castiñeiras et al. 210), and distal parts of the Gondwanan continental margin at the bottom (basal allochthon, Martínez Catalán et al. 1996). Sandwiched in an intermediate suctural position, several ophiolitic units appear, including relicts of a Cambro-Ordovician back-arc (Arenas et al. 2007; Sánchez Martínez et al. 2007a), a possible record of Ordovician oceanic crust (Pin et al. 2006), and Early Middle Devonian suprasubduction-zone type ophiolites (Díaz García et al. 1999; Pin et al. 2002, 2006; Sánchez Martínez et al. 2007b; Gómez Barreiro et al. 210). 


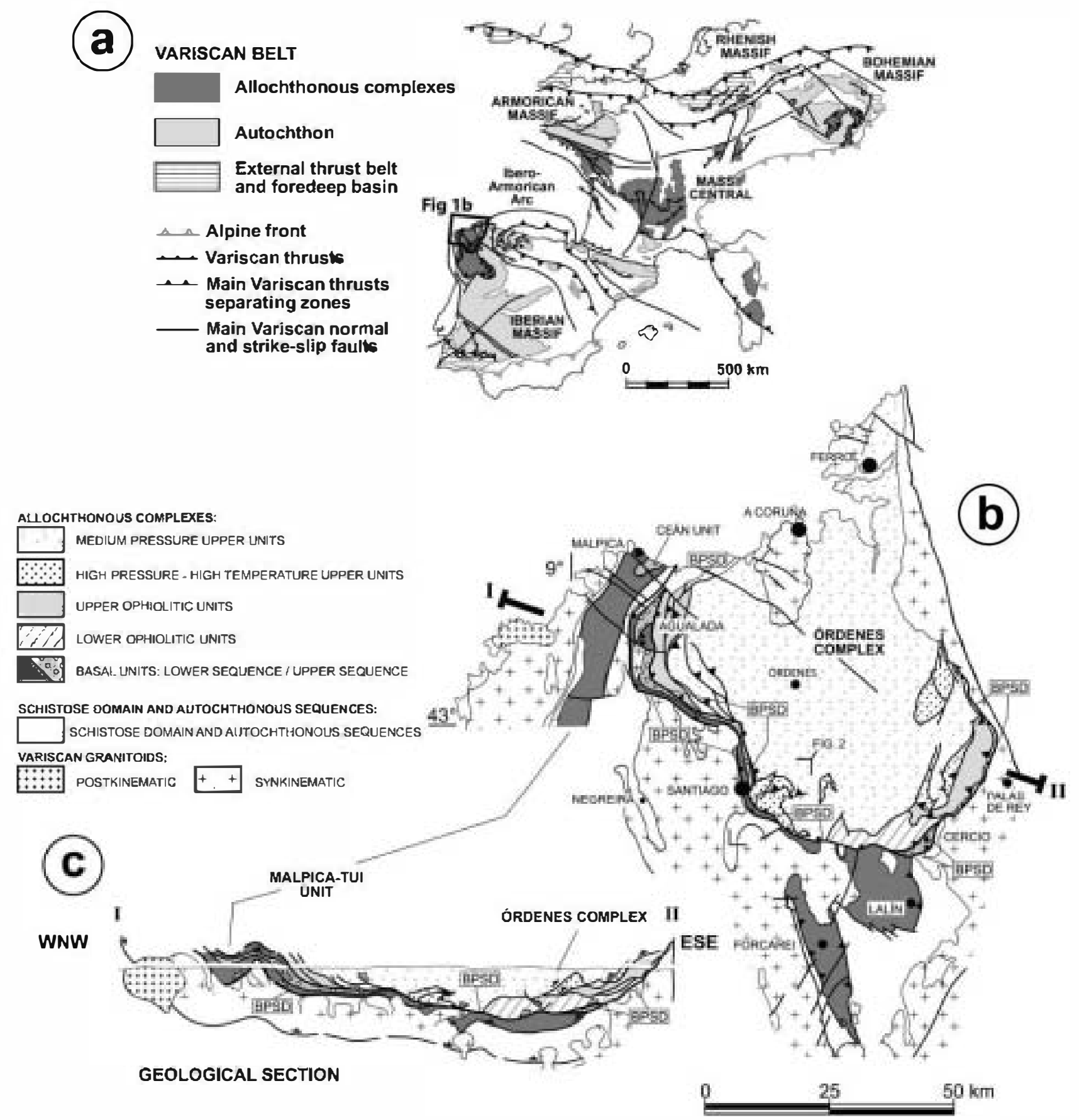

Fig. 1. (a) Location of the study area in the Variscan belt of Europe; (b) map showing the allochthonous complexes of Órdenes and northern half of Malpica Tui in Galicia, NW Spain; (c) a representative cross-section showing the general structure. The nappe stacking and the position of the lower and upper sequences within the basal allochthon should be noted. Top-to-the-ESE kinematics •ften represents thrusting, whereas top-to-the-WTVW kinematics is related to extensional collapse and reactivation of previous structres. BPSD, Bembibre Pic Sacr detachment system. The løcation of Figure 2 is indicated. A fter Gómez Barreirø et al. (2007) and Díez Fernández et al. (210).

The stacking erder of the allechtheneus units repreduces the evolving palaeogeographical scenario in the northern Gendwanan margin. This includes the develepment and drifting away of an ensialic island arc (upper allechthen) leaving behind a leng histery of crustal extensien in Gendwana (Abati et al. 2010), which culminated with the birth and spreading of the Rheic
Ocean (ephielitic allechthen). The clesure of this eceanic realm marked the beginning of the assembly of Pangaea (Gémez Barreir et al. 210), which started in the European Variscides with the subduction of the outermest continental margin of Gendwana, represented by the basal allechthen in the NW Iberian Massif. 
Belew the allechthenous units, an imbricate thrust sheet separates the basal, ephielitic and upper units frem the autechthen. It censists of Ordevician and Silurian metasediments and velcanic rocks (Farias et al. 1987; Rodriguez et al. 2004; Valverde-Vaquer et al. 2005), and is known as the parautechthen (Ribeir et al. 1990), the Schistese Demain (Farias et al. 1987), or the lower allechthen (Martínez Catalán et al. 2009). No ephielites have been found either inside this sequence or at its base, and it is considered a relatively distal part of the Gendwanan centinental margin, less distal than the basal allechthen, which underwent early Variscan subduction whereas the Schistese Demain did net.

This study is focused on the basal allochthen in the south. western part of the Ordenes Complex. In this area the basal allechthen consists of terrigenous metasediments and igneous rocks, traditionally grouped under the lecal name of Santiage unit (Martinez Catalán et al. 1997; Fiss 1 and 2), racing the general sucture aleng the western limb of the Ordenes Complex. The upper allechthen en top (Fig. 1) is represented by the
intermediate-P schists and paragneisses of the Pine unit (Figs 1 and 2), and the high-P and high- $T$ metabasites of the Fernás unit (Figs 1 and 2). Evidence discussed below suggests that the ephielitic allechthen was tectenically remeved in this secter (Fi 1). The Schistese Demain schists in this part appear partially melted and intruded by graniteids (Fig. 1).

\section{The basal allechthen in the SW of the Órdenes Complex}

It has been recently recegnized that the basal allechthen comprises twe tectenically juxtapesed metasedimentary sequences, the upper and lower sequences (Fi 1; Diez Fernández et al. 2010). Both of them underwent an initial high-P metamorphic event $\left(\mathbf{D}_{1}\right)$, their $P-T$ conditions varying according to their primary location in a crustal subduction complex. The upper sequence reached blueschist-facies conditions (Arenas et al. 1995; Redríguez et al. 2003; Lépez Carmena et al. 2010) whereas the lower sequence developed eclogite-facies meta-

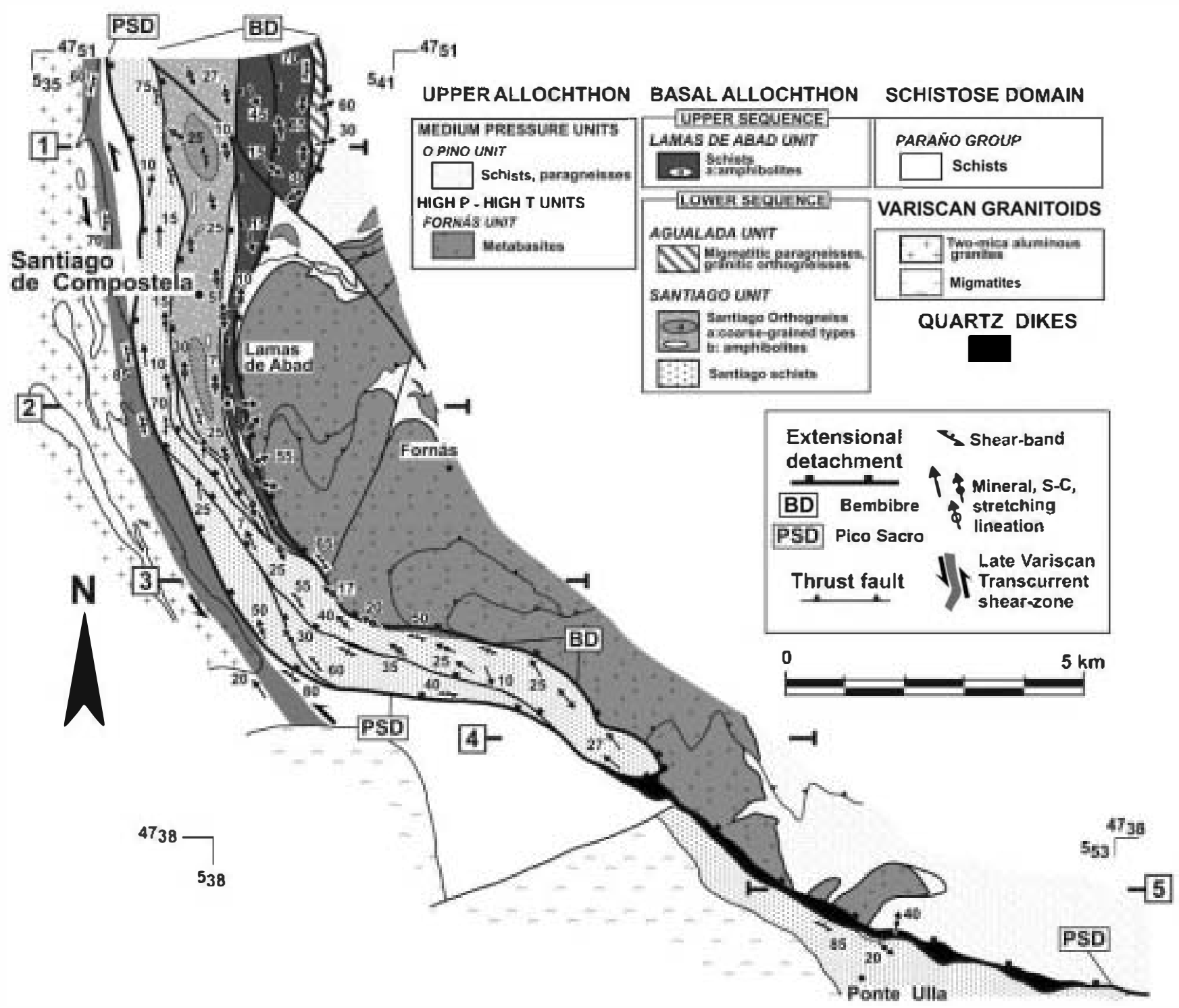

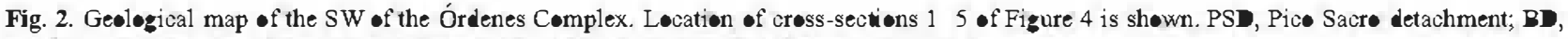
Bembibre detachment. Lineations and shear bands within the basal allochthon are indicated. 
morphism (Gil Ibarguchi \& Ortega Gironés 1985; Arenas et al. 1997; Rubio Pascual et al. 2002; Rodríguez et al. 2003). Based on the lithological association and tectonometamorphic evolution, the Agualada, Santiago, Lalín and Forcarei units belong to the lower sequence. However, new evidence described in detail below demonstrates that the upper half of the Santiago unit should be considered a distinct assemblage, belonging to the upper sequence (Fig. 1). The Cercio unit, composed of an alternation of micaschists and amphibolite lenses, may be included in the upper sequence, although no waces of a high- $P$ event have been found.

A second tectonothermal episode $\left(\mathbf{D}_{2}\right)$ later affected the upper and lower sequences. It is related to the exhumation of the units through a combination of recumbent folding and thrusting with a general top-to-the east movement (Martínez Catalán et al. 2002). Differences exist here as a result of the formation of an inverted metamorphic zoning, from high- $T$ amphibolite-facies conditions at the top to low- $T$ amphibolite- to greenschist-facies conditions below. This event is related to the thrusting of lower sequence units (e.g. Agualada unit) over upper sequence ones (Fig. 1; Arenas et al. 1995; Rubio Pascual et al. 2002; Gómez Barreiro 2007)

A third event $\left(\boldsymbol{D}_{3}\right)$ may be identified, which is closely related to late orogenic readjus ments. Regional-scale extensional detachments, north south upright folding and strike-slip shear zones heterogeneously overprint and rejuvenate the previous tectonometamorphic architecture, mostly under low-grade conditions (Gómez Barreiro et al. 2007). This is the episode that will be explored in detail below.

\section{Tectonometamorphic units}

A detailed analysis has been carried out on the SW branch of the basal allochthon, in the Ordenes Complex, where a continuous section crops out from the upper allochthon at the top to the Schistose Domain at the bottom (Figs 2 4). The geological cross-section reveals a complex discibution of shear zones and retrogression, resulting in stuctural mixing of several lithotypes and tectonothermal events. The basal allochthon in the SW of the Ordenes Complex has been raditionally considered to be represented by the Santiago unit (Arenas et al. 1995; Rubio Pascual et al. 2002; Martínez Catalán et al. 2009), but evidence presented below suggests that the boundaries of the Santiago unit should be revised, and that more tectonometamorphic units are involved. The units recognized at present are described below in structural order from top to bottom (east to west geographically; Fig. 4).

Agualada unit. This unit here is composed of well-preserved metre- to kilomere-sized lenses of migmatitic paraneisses and ranitic orthogneisses (Figs 5, 6a and b). The migmatitic paraneisses, which are semipelitic in origin, show a strong schistosity defined by muscovite, which is progressively replaced by biotite. Plagioclase and quartz are recrystallized in a mosaic texture. Small idiomorphic garnets appear included within plagioclase and biotite crystals. White mica aggregates and small needles of aluminosilicates are also found. The paraneisses are spatially linked to leucocratic melts, which are made up of plagioclase, quartz, biotite and garnet. Rutile is preserved within garnet, whereas ilmenite is the Ti-phase in the matrix. Spatial relationships and mineralogy suggest a migmatitic origin. Small to medium rain-size granitic orthoneisses are locally preserved. Their mineral composition includes quartz, K-feldspar (microcline), biotite and garnet.

The lithological and mineral assemblage indicates a higher metamorphic grade than in the underlying schists, being compatible with high-temperature amphibolite-facies conditions. Given the equivalent structural position within the basal allochthon and

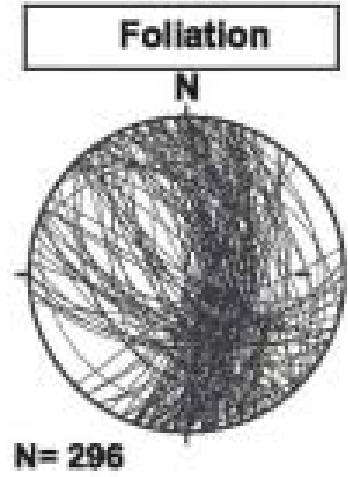

$\mathrm{N}=\mathbf{2 9 6}$

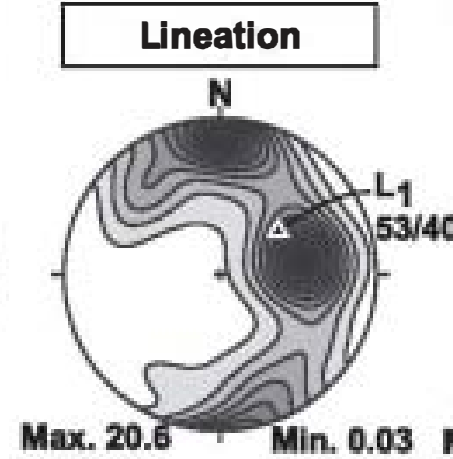

$\mathrm{N}=150$

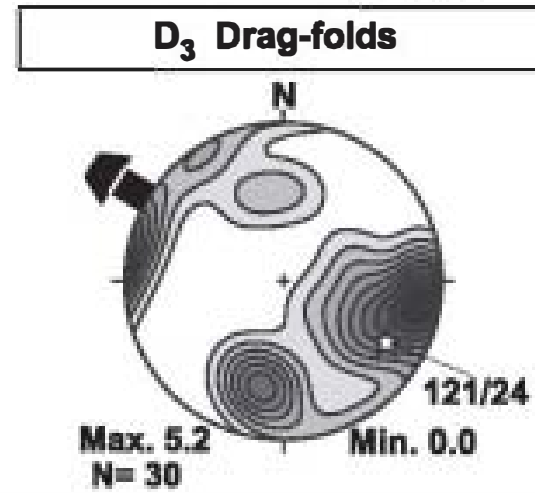

$\mathrm{N}=\mathbf{3 0}$

\section{Shear bands (SCC')}

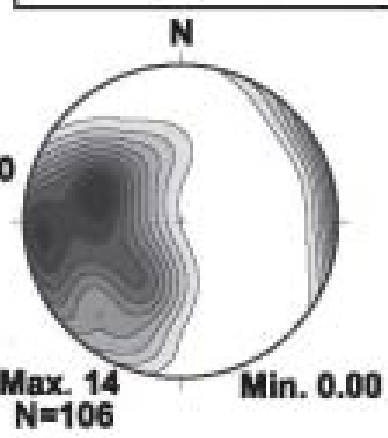

$\mathrm{N}=106$

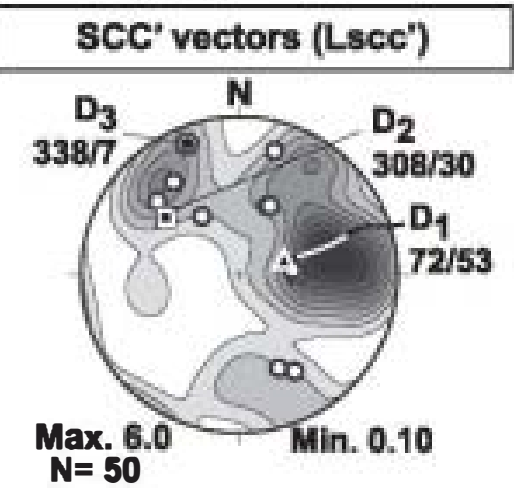

Fig. 3. Smuctural features of the SW of the Órdenes Complex summarized in stereograms. The foliation, lineation and shear bands (SCC') are shown for units of the basal allochthon. $\mathrm{L}_{\mathrm{SCC}}$ vectors for $\mathbf{D}_{1}$, $\boldsymbol{D}_{2}$ and $\boldsymbol{D}_{3}$ are indicated. Open circles represent distinct directional groups of $\mathbf{D}_{3}$ $\mathrm{L}_{\mathrm{SCC}}$ vectors. The movement direction derived from axes of $\mathbf{D}_{3}$ drag folds associated with the hanging wall of the Bembibre-Pico Sacro detachment is also plotted. Lower hemisphere projection. 


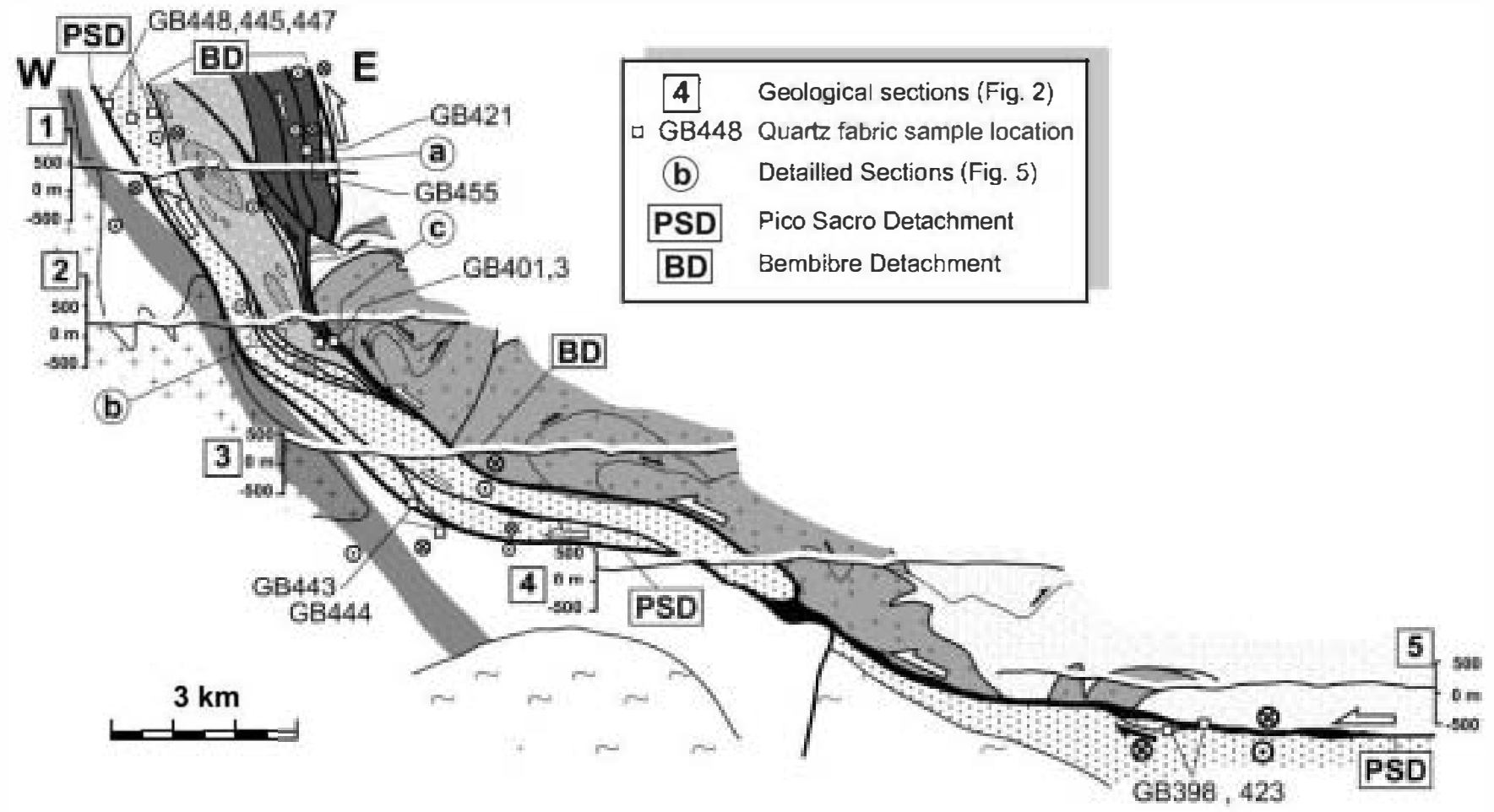

Fig. 4. Composite geological cross-section of the SW of the Órdenes Complex. The location of cross-sections 15 is indicated in Figure 2. L cross-sections $\mathrm{a}, \mathrm{b}$ and $\mathrm{c}$ for Figure 5 is shown. The sample locations for quartz universal-stage crystallographic analysis are indicated (Fig. 9).

petrological similarities, these migmatitic gneisses represent here the southern prolengation of the Agualada unit, which belengs to the lewer sequence units (Fi. 1), eccupying an equivalent suctural pesition within the basal allochthen. There, $\boldsymbol{P}-T$ estimations from eclegitic lenses yielded conditions of $15 \mathrm{kbar}$ and $720^{\circ} \mathrm{C}$ (Arenas et al. 1997). Although ne eclegites have been found to date in our study area, percelegical evidence suggests a linkage between the twe segments of the basal allochthen. Mereover, late retrogression here is mere intense than in the Agualada unit to the nerth, and should have had the effect of blurring the metamerphic recerd.

The erthogneisses locally developed an SC fabric (Berthé et al. 1979; Lister \& Snoke 1984), with a general top-to-the-west sense of shear. Within C-planes, retrogression is marked by the presence of chlerite, white mica and miner epidete, suggesting greenschist-facies conditions $\left(\mathbf{B}_{3}\right)$. This fabric evelves acress a gradient towards we phyllenites outside the orthogneisses, leading to a complete retrogression of the primary assemblages, where a mixture of chlerite, quartz and white mica defines a new fabric $\left(\mathrm{S}_{3} ;\right.$ Fis. $\left.7 \mathrm{c}\right)$.

Lenas de Abad unit. Underlying the Agualada unit a strengly mylenitized schistese unit eccurs, with a penewative mylenitic foliation marked by quartz ribbens and mineral shape erientation (Figs 6c, $d$ and 7a). Lenses of metabasites with hemblende, plagioclase, zoisite, titanite, rutile and chlerite are intercalated with the metasediments. Veins of plagioclase, quartz and zoisite are locally abundant in clese relation to shear zenes. Pelitic to semipelitic micaschists show a main fabric that includes coarse garnet and plagieclase perphyreblasts (maximum $6-8 \mathrm{~mm}$ ), white mica, quartz, biotite, rutile, ilmenite, chlerite, epidete and clinezoisite. Plagioclase appears preferentially concentrated in layers. Interestingly, arnet shews two distinct textural pesitiens: (1) micaceus demains, in which small and idiemerphic garnet grains grow in equilibrium with white mica; these demains appear beunded by late C' shear bands, with a top-to-the-NW sense of shear, in which a greenschist-facies mineral asseciation develops (- Fig. 6c); (2) large syntectenic perphyroblasts displaying an internal foliation $\left(\mathrm{S}_{\mathrm{i}}\right)$ roughly defined by rutile and epaque minerals. The internal foliation shews continuity with the external feliation and, in some cases, snewball geemery. Gamet perphyroblasts develep $\sigma$ and $\delta$ types within most deformed levels, which is in accerdance with a general top-to-the-east SCC' fabric (Figs $6 \mathbf{d}$ and $7 \mathbf{g}$, i).

Taking inte account all these features and its structural pesition, the Lamas de Abad unit can be tentatively correlated with other units of the upper sequence in the basal allochthen. To the west, in the Cean unit, whese mineral assemblages indicate equilibrium under blueschist-facies cenditions, the schists display similar mineral assemblages and textural relationships, whereas the metabasites show censpicueus lawsenite pseudemerphs, and retregression through amphibelite and greenschist facies (Gil Ibarguchi \& Ortega Girenés 1985; Redríguez Aller 2005; López Carmena et al. 2010). Te the east, the Cercie unit eccupies an equivalent smuctural pesition and shows a similar lithelegical asseciation, but absence of high-P event. Similarities as well as differences suggest that the Lamas de Abad unit represents the same tectenes atigraphic sheet as the Ceán and Cerci units, and eccupied an intermediate pesition between them in an east-west-eriented strike section (Fi . 1).

Sentiago unit. This unit consists of twe main lithelegies: Santiage schists belew and Santiage erthegneiss abeve. A narrew band -f Santiage schists als eccurs between the Lamas de Abad unit and the Santiage erthegneiss, clese to the city of Santiage de Compestela (Figs 2, 4 and 5), but to the nerth the Lamas de Abad unit appears in centact with the Santiage erthegneiss. This supperts a subwactive character for the centact, suggested by the 

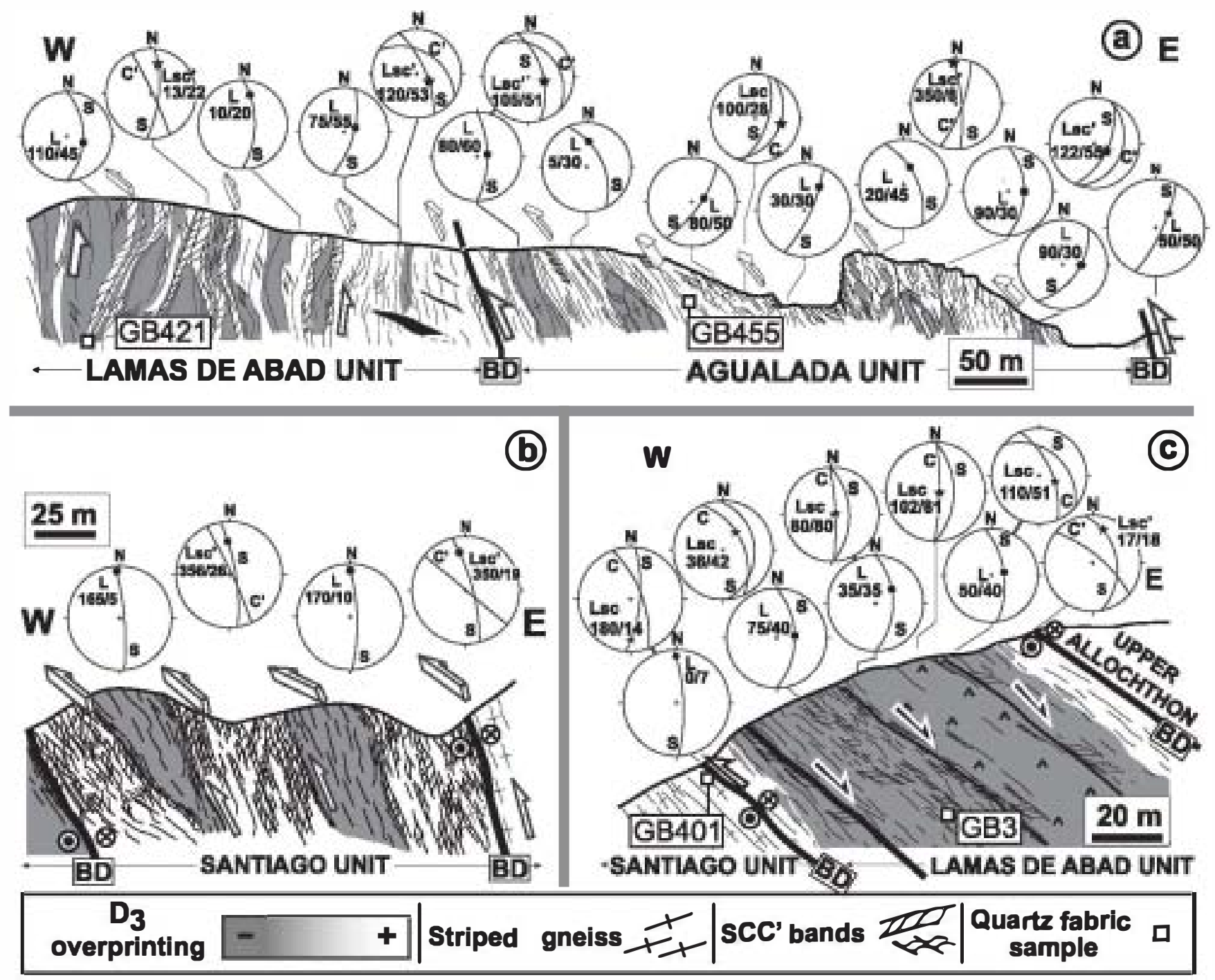

Fig. 5. Representative field geological sections of the Rembibre detachment shear zone. $\mathbf{D}_{3}$ overprinting is indicated; dark grey indicates no $\mathbf{D}_{3}$ overprinting. Shape (L and S) and SCC' fabric orientations are represented in equal angle, lower hemisphere stereograms. (a) Tectonic ransition from the upper allochthon to the top of the basal allochthon, and the contact between the Agualada and Lamas de Abad units. A phyllonitic network was developed in both units. (b) Condensed transition from the upper allochthon to the Santiago orthogneiss. The Lamas de Abad unit shows a consistent top-to-the-ENE kinematics. (c) Lower contact of the Santiago orthogneiss with the Santiago schists. Striped gneisses appear in contact with phyllonites, with a consistent top-to-the-NNW sense of shear. The location of samples of Figure 9 is indicated.

fact that metasedimentary sequences above and below the ranitic neisses differ not only in composition but also in their metamorphic evolution. It also suggests a tabular shape for the orthogneiss before the development of the contact, because its upper and lower boundaries are parallel. The parallelization was acquired during ductile deformation associated with both subduction and exhurnation by recumbent folding and thrusting (Diez Fernández \& Martínez Catalán 2009). However, the orientation of the tectonic upper contact, parallel to the bottom of the orthogneiss, suggests a reactivation of the lithological contact.

Santiago schists. This is the most common lithology below the Lamas de Abad unit. The schists are semipelitic metasediments with distinct syntectonic albite porphyroblasts, which appear elongated parallel to and marking a mineral lineation. The schists are heterogeneously phyllonitized and retrogessed, especially in the vicinity of the main contacts (Fig. 6e). Mineral inclusions within albite porphyroblasts define an internal foliation $\left(S_{i}=S_{1}\right)$ that has been barely cansposed, representing a relic of a highpressure low-temperature assemblage ( $\mathbf{D}_{1}$; Arenas et al. 1995).

Differences in mineral composition exist within the schists above and below the Santiago orthogneiss. Schists above show an $S_{2}$ foliation defined by biotite, white mica, quartz, plagioclase and chlorite, with minor ilmenite, titanite and garnet. Within albite porphyroblasts, the rain-size range of inclusions defining $S_{i}$ is $50200 \mu \mathrm{m} . S_{i}$ is defined by small garnets and oriented crystals of white mica, epidote, rutile or ilmenite, chlorite and quartz. White mica (WM, Fig. 6e) has been identified as phengite (Arenas et al. 1995). This mineral assemblage can be correlated with a low- $T$ eclogitic event related to the subduction of the basal allochthon $\left(\mathbf{D}_{1}\right)$. Below the orthogneiss, the main fabric $\left(\mathbf{D}_{2}\right)$ is defined by white mica, chlorite, plagioclase, quartz, ilmenite and titanite. Mineral inclusions in albite are very small $(<1 \bullet \mu \mathrm{m})$, 


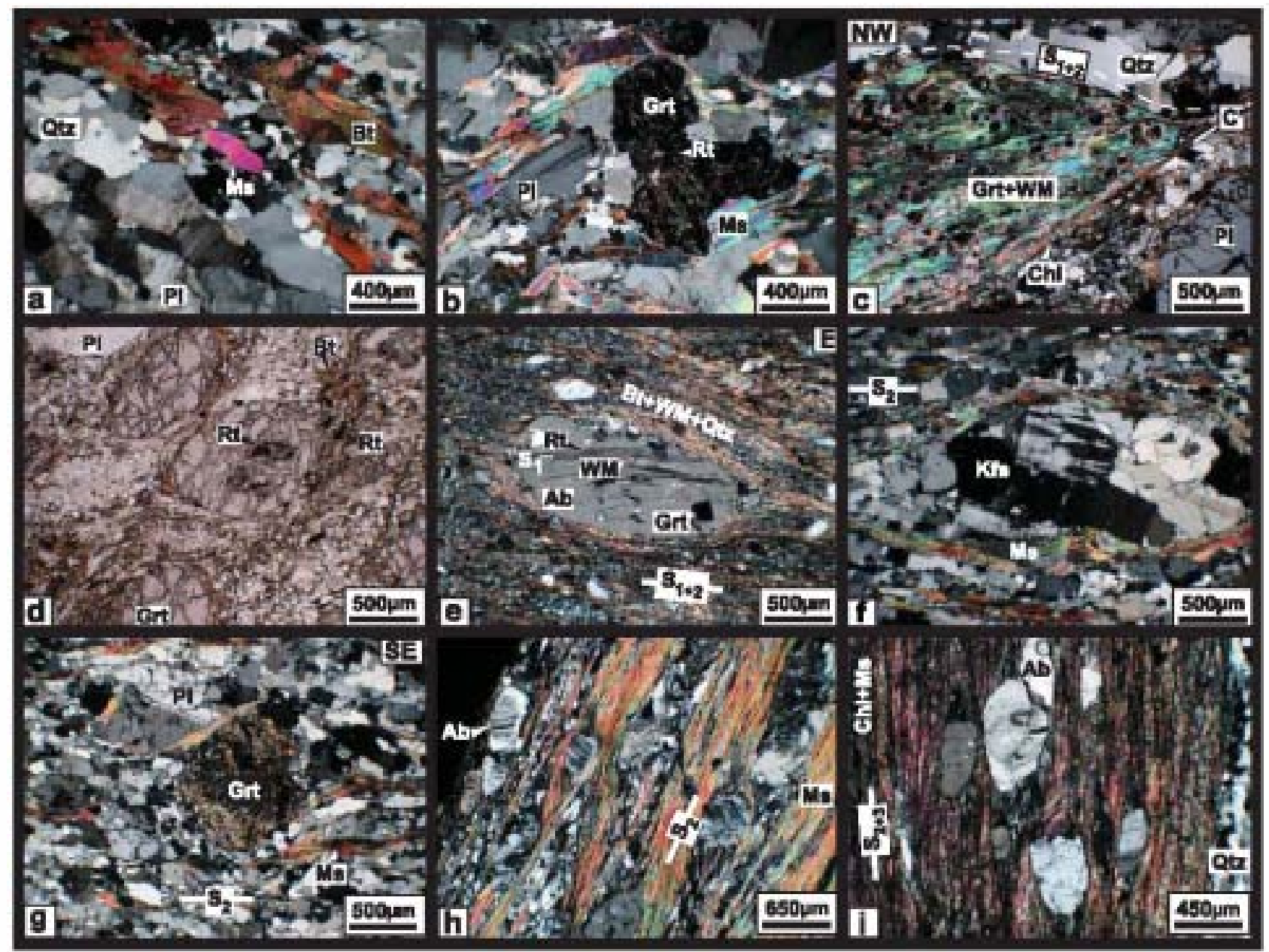

Fig. 6. Micrestnctural features $\bullet$ the basal alløchthon in the SW Órdenes Complex. (a, b) Migmatitic paragneisses $\bullet$ the Agualada unit. (c, d) Lamas de

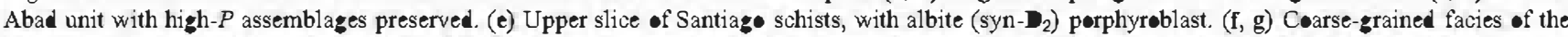
Santago orthøgneiss, where the mylonitic foliation defined by muscovite $\left(S_{2}\right)$ surrounds igneous $\mathrm{K}$-feldspar porphyrøclasts (Kfs; $\mathrm{f}$ ), and gamet $(\mathrm{Grt} ; \mathrm{g})$. (h, i) Lower slice of the Santiage schists, where albite porphyroblasts show a very fine $S_{i}$ with rutle (Rt), carbonaceous inclusions and epidote. The main foliation is defined by muscovite (Ms), chlorite (Chl) and quartz (Qtz).

defining an $\mathrm{S}_{\mathrm{i}}=\mathrm{S}_{1}$ feliation by a mixture of carbenaceeus inclusiens, white mica, rutile er ilmenite needles, quartz and probably epidete (Fig. 6h and i). Differences in $\mathrm{S}_{1}$ grain size and mineral assemblages suggest that the schists below the Santiage erthegneiss reached lexer-grade cenditiens during $\mathbf{D}_{1}$ metamerphic peak. Furthermore, differences found in the regional foliation $\left(\mathrm{S}_{2}\right)$ show that the upper schists reached the biotite zone, whereas the lewer schists never exceeded the chlerite zone (Gémez Barreir 2007), which supperts the metamerphic inversion identified to the north by Arenas et al. (1995).

It should be noted that the regional foliation $\left(\mathbf{D}_{2}\right)$ at the bettem of the Santiage unit was lecally everprinted by andalusite- and (locally) sillimanite-bearing assemblages, compesed of muscovite, plagieclase, aluminesilicate, chlerite, quartz and bietite, which correlate with incipient partial melting at deeper levels in the Santiage schists crepping out to the south of the area (Figs 2 and $7 \mathrm{~b}$ ). Rotated andalusite porphyroblasts indicate synkinematic growth during top-te-the-nerth shearing. Low-P and intermediate- to high- $T$ cenditions have been suggested for this lecalized event ( 3 ; Gémez Barreire 2007).

Santiago orthogneiss. Granitic gneisses cropping out as a tabular bedy (Figs 1,2 and 4) divide the Santiage unit inte towe tectenic slices. Their thiclmess is drastically reduced frem roughly $1 \mathrm{~km}$ to less than $5 \mathrm{~m}$ in the southern part of the area. The erthogneiss shews a mylenitic foliation with quartz, $\mathrm{K}$ feldspar (microcline), white mica and garnet. Other phases include chlorite, apatite, epidete, biotite and ilmenite or titanite (Díaz Garcia 1990; Gémez Barreir 2007). The plutenic erigin of the erthegneiss is deduced frem textural criteria (Díaz García 1990). Coarse fabrics deminate the inner parts of the massif (Figs 6f, and 8), with a gradual cansition towards striped gneisses with a streng mylenitic foliation clese to the boundaries (Fig. 7e). Amphibelite lenses, probably representing mafic dykes, have been identified (Fi . 2), whereas similar rocks the nerth preserve eclegitic assemblages (Rubi Pascual et al. 2002).

Lithelogical asseciation and metamerphic evelution correlate with lewer sequence units in the basal allechthen to the west (Fig. 1; Malpica-Tui complex; Redríguez Aller 2005; Díez Fernández et al. 2010). Mineral assemblages and regienal evidence suggest that after the eclegite-facies event $\left(\mathbf{D}_{1}\right)$, mylenitic fabric re-equilibrated under amphibelite-facies cenditiens ( $\mathbf{D}_{2}$; Rubie Pascual et al. 2002). It has been argued that the 


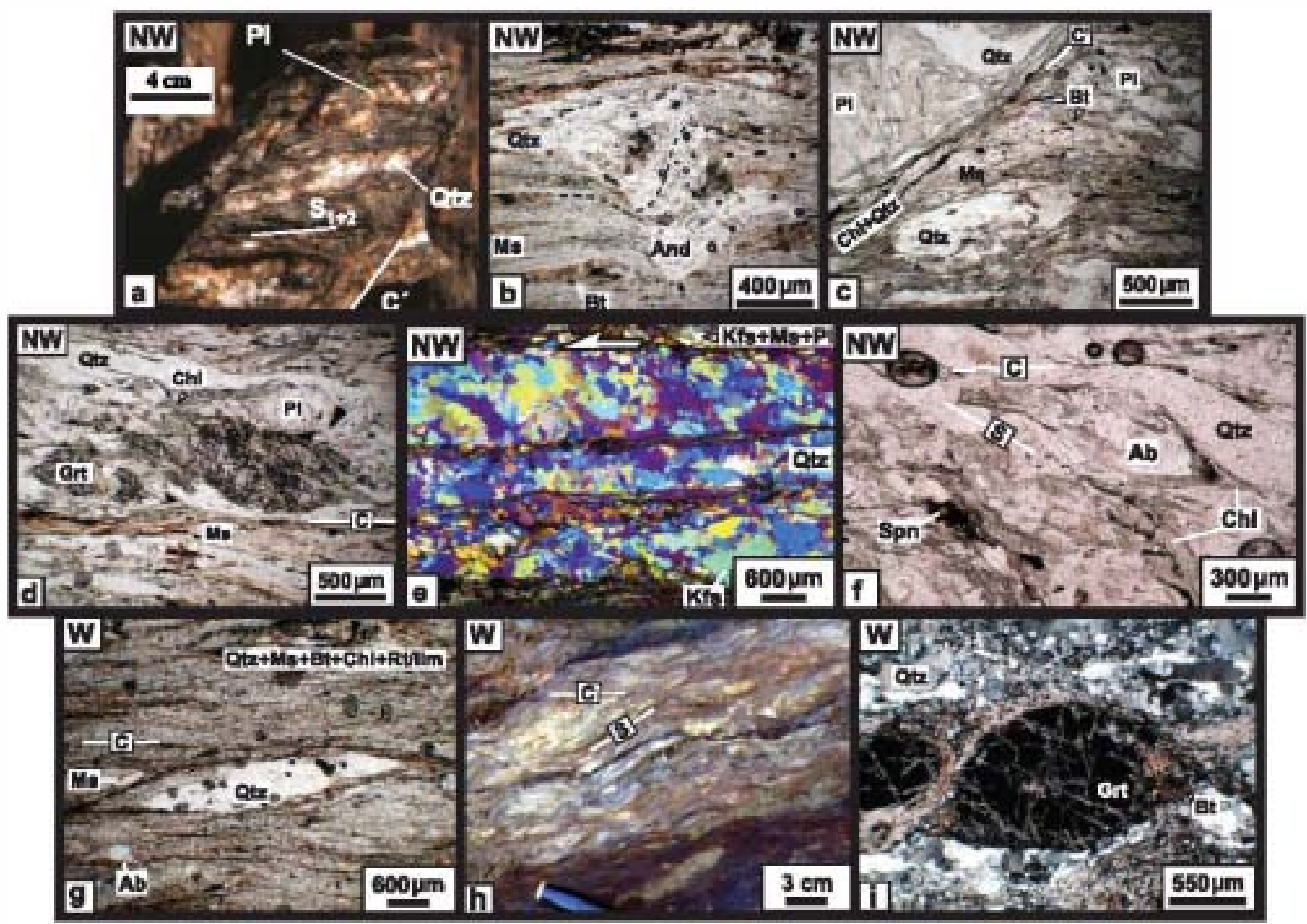

Fig. 7. Micrestnuctures and kinematic criteria from the main shear zones. (a) Lamas de Abad schist, with $\mathbf{D}_{3} C^{\prime}$ shear bands cutting $S_{1+2}$ f by quartz ribbons, plagioclase-rich bands and micaceous domains. (b) Syn- $\mathbf{D}_{3}$ andalusite porphyroblast from the bottom of the Santiag• unit. Rotation path and quartz strain-shadows indicate a top-to-the-NW shearing. (c, d) Phyllonites from the Bembibre detachment shear zone, with an SCC' fabric affecting the gneisses of the Agualada unit (c) and Lamas de Abad schists (d). Relics of previous assemblages are recognized across the fabric, defined by chlorite, quartz and muscovite. (e) Striped gneisses from the top of the Santiago orthogneiss. Dynamically recrystallized quartz ribbons and feldspar muscovite-rich bands define the mylonitic fabric. Oblique foliation defined by preferred orientation of quartz grains shows a top-to-the-NW shearing. SC fabric from the lower slice of the Santiag schists. (f) Albite porphyroblasts with $S_{i}=S_{1}$ and $\sigma$-shape. Mineral assemblage includes muscovite (Ms), quartz $(\mathrm{Qtz})$, albite $(\mathrm{Ab})$ and itanite $(\mathrm{T} \mathbf{n})$. (g i) Mylonites from the Lamas de Abad unit, where SC, mica fish and oblique foliation defined by recrystallized quartz grains point to a top-to-the-east shearing. WM, white mica.

relatively scarce eccurrence of biotite in the $S_{2}$ erthogneiss fabric may suggest relatively high-P conditions at the beginning of the $\mathbf{D}_{2}$ event (e.g. Redriguez Aller 2005). Later, the Santiage erthegneiss was affected by a deformation event, which led to its ransfermation inte an ul amylenitic-phyllenitic fault reck. This change eccurred preferentially aleng the beundaries and includes pregressive replacement of $\boldsymbol{D}_{2}$ mineralegy by $\boldsymbol{D}_{3}$ synkinematic lewer-temperature assemblages including chlerite, quartz, epidete, sericite and albite, ameng other minerals, suggesting greenschist-facies conditions during top-to-the-north shearing (Gómez Barreire et al. 2007).

\section{Kinematic and deformation analyses}

The tectenic beundaries of the basal allechthen in the area have been a matter of debate (Van Zuuren 1969; Diaz García 1996; Martínez Catalán et al. 202). The main boundaries have been described as thrusts, lew-angle nermal faults, extensional detach- ments and, partially, strike-slip shear zenes (Gémez Barreire et al. 2067, and references therein). In a preliminary appreach to explain such kinematic variation, the rele of the reactivation was explered. It became evident that at least a part of the tectenic contacts in the study area and their regienal prelengations aleng the basal allochthen showed evidence for leng-term activity during the Variscan eregeny (Gémez Barreire et al. 2003). Previously defined units appear separated by tectenic beundaries (Figs 4 and 5), mest of which developed or were reactivated during $D_{3}$

The kinematic analysis of the tectenic boundaries was carried out in lecalities where perolegical and suctural criteria indicate a weak everlapping of the deformation phases. Shear band fabrics (SCC'; Lister \& Sncke 1984; Blenkinsep \& Trelear 1995) were analysed. The SCC' flew vecter $\left(\mathrm{L}_{S C C^{\prime}}\right)$ (Figs 3 and 5) was calculated pletting the $S$ - and C-plane intersection vecters int a stereoplet, and rotating the intersection vecters $90^{\circ}$ within the $\mathrm{C}$ or $\mathrm{S}$ planes, in $\mathrm{SC}$ and $\mathrm{SC}^{\prime}$ fabrics, respectively. This is 


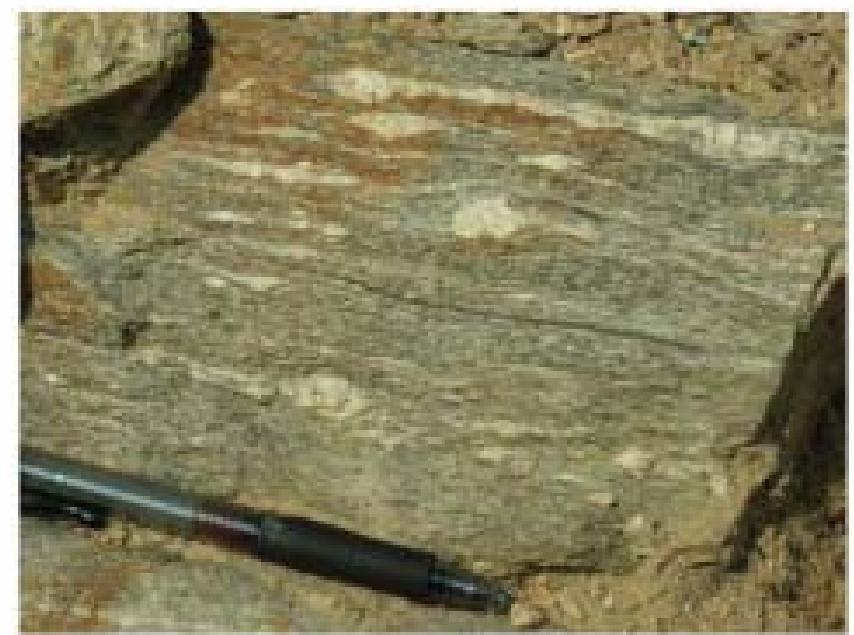

Fig. 8. Kinematic criteria in the quarry of Meixonfrí, to the north of Santiago de Compostela, and corresponding to the inner part of the Santiago orthogneiss. The kinematics of $\mathbf{D}_{2}$ thrust-related ductile shearing is indicated by $\sigma$-type porphyroclast systems as being top-to-theSE (right). The attiude of the mineral lineation is $13 \%^{\circ} / 10^{\circ}$ SE. The pen for scale is $8 \mathrm{~cm}$ long.

justified because the $S$ planes in SC' fabrics are cleser the general flew plane in the shear zene. Crystallegraphic preferred erientation of quartz $c$-axes and subgrain beindaries (SGB) were measured in selected quartz-rich tectenites with a universal stage (Fig. 9). Subgrain beundaries lying at a low angle to $c$-axes are censistent with in wacrystalline flew parallel to the (101) quartz basal plane. Sterengraphic prejection of subgrain beundary peles $(\pi \mathrm{SBG})$ has been considered an appreximation to the distribution - quartz a-axes (Bouchez 1978; Trépied et al. 1980; Okudaira et al. 1995). Crystallographic fabrics were precessed using Steree 32 v.1. 1 seftware (Röller \& Trepmann 2008). The macrescepic feliation $\left(S_{A}\right)$ and the shape fabric defined by dynamically recrystallized grains $\left(\mathrm{S}_{\mathbf{E}}\right)$ were pletted in the stereegrams (Knipe \& Law 1987). Other criteria were als considered, such as mantled perphyreclasts, mica fish and asymmeric folds, accerding to the metheds develeped by Simpsen \& Schmidt (1983) and Passchier \& Treuw (1996). The structural sequence that emerges from the micrestructural and kinematic analysis is described below.

First phese $\left(\boldsymbol{D}_{1}\right)$ : continental subduction. The subduction-related $\mathbf{D}_{1}$ kinematics remains somewhat enimatic, as enly indirect evidence such as the regional distribution of metamerphic zones has previded a westward compenent (in present coerdinates) for this episede of centinental subduction (Arenas et al. 1995; Martínez Catalán et $\boldsymbol{a l}$. 1996, 2009). The accompanying metamerphic peak assemblages seem to be preserved in the Santiage unit mainly as an internal foliation $\left(\mathrm{S}_{\mathrm{i}}=\mathrm{S}_{1}\right)$ within albite perphyreblasts. The discentinueus nature of $S_{i}$ and the streng $\mathbf{D}_{2}$ everprint prevent the use of this foliation as a $\mathbf{D}_{1}$ kinematic criterion. This is alse the case for the Agualda unit, where enly scarce micreinclusiens in plagioclase may be considered wue $\mathbf{D}_{1}$ fabrics. On the ether hand, well-preserved fabrics defined by garnet-white mica-rutile-quartz assemblages in the Lamas de Abad unit peint to a high-pressure equilibrium, and represent petential relics of the $\mathbf{D}_{1}$ kinematics. Smuctural analysis supperts the preservation of a distinct shape fabric (lineation and foliatien) acress the Lamas de Abad unit (Fi 5b). Whereas the foliation appears to be eriented almest parallel to the surrounding $\mathbf{D}_{2}-\mathbf{D}_{3}$ fabrics, the mineral lineatien is at high angle to the $\mathbf{D}_{2}-$ $\mathbf{D}_{3}$ flow directions (Figs 2,5 and 9), showing a NE-SW wend $\left(\mathrm{L}_{1}=53^{\circ} / 40^{\circ} \mathrm{N}\right.$; Fiss 3 and 5$)$.

SC fabric analysis shews a persistent top-to-the-east sense of shear, with $\mathrm{L}_{S C}=72^{*} / 53^{\circ} \mathrm{E}$ en average (Figs 3-5). Quartz $c$ axes show a streng preferred erientation with a pattern defined by a single peripheral maximum clese to the pole of the shear zone boundary and the mylenitic foliation (e.s. GB 3, Fig. 9). The top-to-the-east meneclinic symmery is alse supperted by the preferred erientation of subgrain boundaries, which geomewically correlate with the a-axes. Quartz $c$-axis patterns suggest that a simple shear compenent deminated during the fabric development. This is in accerdance with the scarce development -f C'C" shear bands. Quartz crystallegraphic fabrics may be interpreted in terms of deminant intracrystalline slip systems, swe could make some suggestions about defermation conditions (e.g. Lister et al. 1978; Law et al. 1994). Classical interpretation of $c$ - and $\boldsymbol{a}$-axis patterns suggests that slip on basal $\langle\boldsymbol{c}\rangle$ slip and miner themb $<>$ systems may be active during deformatien (e.g. Schmid \& Casey 1986). Thermal conditions of this intracrystalline flow are consistent with the metamerphic evelution described previously (e.s. Okudaira et al. 1995; Kurz et al. 2002; Toy et al. 2008).

Mica fish, mantled $\sigma$ - and $\delta$-type perphyreclasts and asymmeric micrefolds als suppert the same kinematics (Fig. 7 and i). It sheuld be neted that garnet perphyroblasts shew a snewball geomeny with $S_{i}$ defined, for example, by rutile in continuity with the external foliation, where rutile is als stable. Gamet shows $\delta$ and $\sigma$ shapes, which may suggest some ductile behaviour of this mineral. All these features suggest that the mylenitic fabric in the Lamas de Abad sector was developed under high-P cenditions. Hewever, we are aware that partial re-equilibration of the fabric towards lewer-pressure cenditions during the beginning -f the exhumation precess may mask $\mathbf{D}_{1}$ kinematics. Additionally, initial $\mathbf{D}_{2}$ stages in the area might have alse developed under general high-P (>12 kbar) conditions, as decumented for structurally equivalent demains in other segments acress the upper sequence in the basal allechthen (Arenas et al. 1995; Lepez Carmena et al. 210). In that sense, the Lamas de Abad fabrics sheuld be considered wansient between $\mathbf{D}_{1}$ and $\mathbf{D}_{2}\left(\mathrm{~S}_{1+2}\right.$; Fis. 6c). This is alse censistent with variations in flew direction between top-te-the-NE and top-to-the-SE shearing (Fig. 5).

Second phase $\left(D_{2}\right)$ : thrust-related exhumation. This stage led to the develepment of a regienal fabric aleng the basal allechthen in the upper and lewer sequences. In the Agualada unit, the main fabric was established during this stage under general amphibelite-facies conditions. This is als recegnized at some levels of the Lamas de Abad unit, where the main feliation partially reequilibrated the $\boldsymbol{D}_{1}$ assemblages with a conspicueus bietite growth from gamet. In the Santiage unit, a pervasive schistesity $\left(\mathrm{S}_{2}\right)$ was generated in the schists, defined by muscovite, bi tite, syntectenic albite perphyreblasts and chlerite (Fig. 6h and i). A slightly higher grade is recognized in schists abeve the Santiage erthegneiss. Ribbens of dynamically recrystallized quartz are locally abundant (Fi. 7e).

The main fabric in the Santiage erthegneiss develeped at that time. Central regiens of the erthegneiss exhibit cearse-grained types, where a foliation roughly parallel to its boundaries is defined by white mica, augen feldspars and gamet. Surrounding these areas, mylenitic gneisses with quartz and feldspar ribbens develeped (Fi 7e). Consistent kinematic criteria exist within the inner secters of the Santiage erthegneiss where SC and o-type 


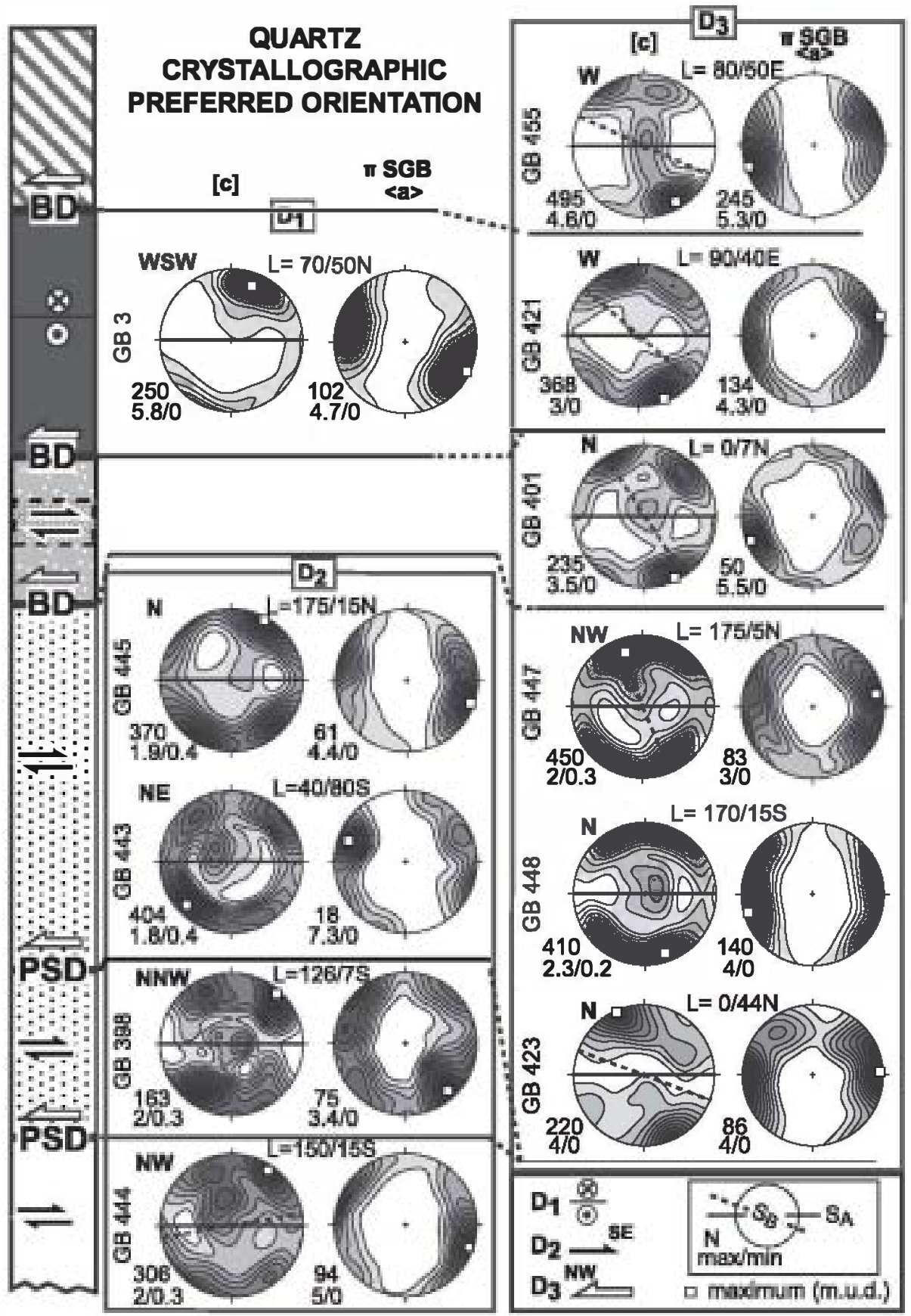

Fig. 9. Selected quartz $c$-axes and subgrain boundary ( $\pi \mathrm{SG} \mathbf{\mathbf { B }} \sim\langle\boldsymbol{u}\rangle$ ) pole figures, measured on the universal stage. Results are shown in a synthesis column where the main tectonic boundaries are included. Code for units as in Figure 3. Equal area, lower hemisphere projections. Density distribution scaled to multiples of the uniform distribution (m.u.d.). $\square$, maximum density. Main foliation $\left(\mathrm{S}_{\mathrm{A}}\right)$ and oblique foliation $\left(S_{\mathbf{B}}\right)$ defined by recrystallized quartz are also indicated. Pole figures are grouped into deformation phases $\boldsymbol{D}_{1}, \mathbf{D}_{2}$ and $\mathbf{D}_{3}$

porphyroclast systems show a general top-to-the-south or -SE sense of shear (Fig. 8). The trend of $\mathbf{D}_{2}$ mineral lineation varies between NW SE and north south (Figs 2 5). To the south, shear zones crop out below the Pico Sacro detachment displaying a clear top-to-the-SE kinematics, as defined by SCC' fabrics $\left(\mathrm{L}_{\mathrm{SCC}}=135^{\circ} / 20^{\circ} \mathrm{SE}\right)$.

Evidence of $D_{2}$ flow has been found also in quartz fabrics across the unit, mainly in the lower part of the Santiago schists (- Fig. 9). $\mathbf{D}_{2}$ fabrics share complex quartz $c$-axis patterns where partially connected girdles and submaxima define a quasiorthorhombic symmetry, suggesting flattening perpendicular to the foliation plane. However, density distribution and the orientation of subgrain boundary poles point to a rotational component of the flow, with a monoclinic symmery, reflecting a top-to-the-
SSE shearing. This is also confirmed by oblique foliation in quartz ribbons, and mica fish. Most of the sub rain boundary poles and $c$-axes are orthogonal (Fig. 9), so we could consider them a qualitative approximation to $a$-axes. Altogether, quartz $c$ axis fabric and SC'C" shear band development point to a stretching shearing behaviour (Passchier \& Trouw 1996). At a regional scale, this phase has been related to top-to-the-SE exhumation of the basal allochthon driven by major recumbent folding and thrusting (Martínez Catalán et al. 1996; Díez Fernández \& Martínez Catalán 2009).

Third phase $\left(\boldsymbol{D}_{3}\right)$ : exhumation during extensional collapse. During this phase most of the rocks in the basal allochthon were affected by ductile deformation, which resulted in retrossion 
of the $\mathbf{D}_{2}$ assemblages. This deformation is closely related to two distinct extensional structures, the Bembibre and Pico Sacro detachments.

The Bembibre detachment. This is a broad, heterogeneous shear zone characterized by the development of a phyllonitic network, which is especially pervasive at the top of the sequence, where it affects the Agulada and Lamas de Abad units (Figs 2 5). Similar features appear heterogeneously distributed across the Santiago schists downward. Mylonitic $\mathrm{S}_{3}$ fabrics anastomose around less deformed domains of the Agualada and Lamas de Abad units (Fig. 5). In the Santiago orthoneiss, mylonitic bands and phyllonites form close to the boundary with the schists (Fig. 5). Whereas schistose lithologies display a penerative SCC' fabric, the orthogneiss evolved from striped neisses to phyllonites.

The mineral lineation across the phyllonitic network and mylonites shows a persistent NNW SSE rend, although variations may occur as a result of interference of shear zones, rigid rotation of blocks between them, and late folding (Figs 2 and 3 ). D deformation progressively concentrated from the initial $1 \mathrm{~km}$ width high-strain zone to discrete metre-size shear zones along boundaries where mechanical contrasts exist, such as the uppermost contact with the upper allochthon, and the schist orthomeiss boundary (Figs 4 and 5). Ductile flow in the Bembibre detachment affects not only the basal allochthon but also the upper allochthon (Gómez Barreiro 2007), where overturned drag folds with west vergence developed in the vicinity of the detachment (Figs 24 and 10). Along the upper boundary, metrescale lenses of talc-schists occur, suggesting that ulramafic lithologies, probably corresponding to the ophiolitic allochthon, were also affected and removed by this structure (Gómez Barreiro 2007).

The analysis of $\mathbf{D}_{3}$ shear bands indicates a persistent top-tothe-NW sense of shear, with NNW SSE $\mathrm{L}_{\mathrm{SC}}$ vectors on average (Fig. 3). Other microstuctures, such as mica fish and $\sigma$-type porphyroclast systems, support this kinematics (Fig. 7a, c and d). It is relatively common to find in both schists and orthogneisses an oblique foliation defined by dynamically recrystallized quartz rains $\left(\mathrm{S}_{\mathbf{B}}\right)$ along the ribbons. This microstucture indicates a dominant top-to-the-NW sense of shear.

Quartz $c$-axis fabrics have complex patterns that range from single maxima to partially connected crossed girdles ( $\mathbf{D}_{3}$; Fig. 9). Most of the samples tend to develop symmetrical patterns with respect to the reference frame. Deviations from that tendency include external and internal asymmetries resulting in consistent top-to-the-NW shearing. The analysis of the subgrain boundaries in quartz supports the existence of this rotational component in the deformation flow (Fig. 9). The sense of shear is consistent with top-to-the-NNW criteria. The association of microstructures and quartz fabrics is compatible with a combination of simple and pure shear during the activity of the Bembibre detachment, which may be considered a stretching shear zone. The existence of a stcetch component parallel to the direction of the flow correlates also with the dramatic thinning of the Santiago orthoneiss to the south.

Geometric analysis of drag folds formed in the hanging wall to the Bembibre detachment can be used to derive kinematic information (Ramsay \& Huber 1987; Wheeler 1987; Passchier \& Williams 1996). Minor and major flexures were systematically examined along the contact (Figs 3 and 4). The results include north south to west east fold axes, with a general vergence to the NW. If we consider the projection of the normal to the fold axes on the fault plane as a slip vector, a consistent top-to-theNW movement $\left(121^{\bullet} / 24^{\bullet} \mathrm{SE}\right)$ can be established (Fig. 3). Towards the bottom of the Santiago unit, the abundance of phyllonites and of kinematic criteria related to the Bembibre detachment decreases, partially deleted by the motion of the Pico Sacro detachment.

The Pico Sacro detachment. This extensional structure partially overprints the Bembibre detachment (Fig. 4). Along the Pico Sacro detachment low-rade brittle ductile to brittle deformation dominates. However, relicts of an early ductile behaviour under higher-grade conditions can be noticed. They consist of low-pressure, high- to intermediate-temperature assemblages at

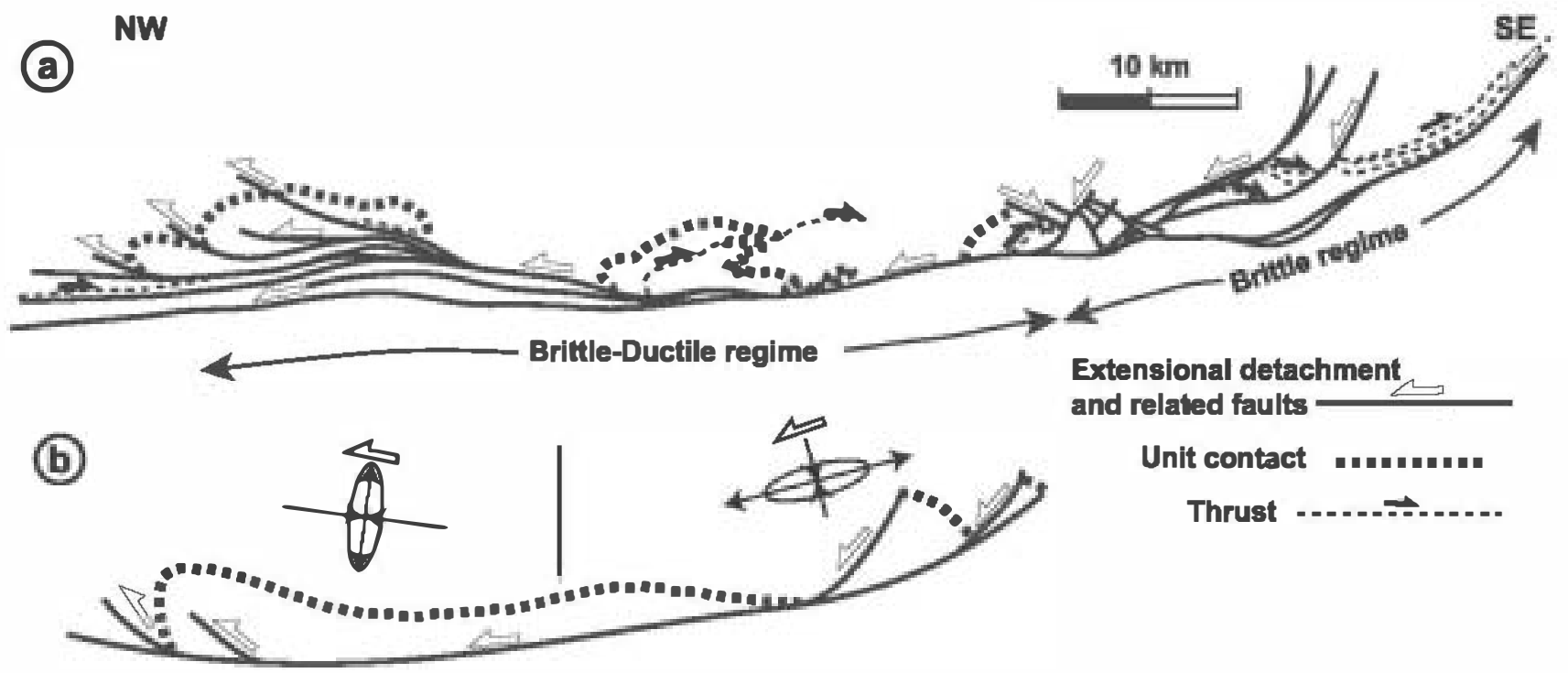

Fig. 10. (a) The Bembibre and Pico Sacro detachments unfolded, showing their mutual relationships and associated structures. Deformation mechanisms indicate that the Pico Sacro detachment cuts progressively higher structural levels to the SE, where normal listric and con jugate faults occur. To the NW, in the direction of movement of the hanging wall, drag folds and reverse faults developed above the Bembibre detachment. (b) Mega-slump model explaining extension at the upper structural levels and shortening at depth in the Bembibre-Pico Sacro detachment system. Based on Gómez Barreiro et al. (2002). 
the bottom of the Santiago unit (Van Zuuren 1969; Gómez Barreiro 2007), where andalusite porphyroblasts with sigmoidal inclusions indicate about $45^{\circ}$ of sinis ral rotation with respect to the external schistosity (Fig. 7b). Asymmetric strain shadows are also present, suggesting a top-to-the-NW shearing, and indicating a syn- $\boldsymbol{D}_{3}$ character for this thermal event

Later evolution of the Pico Sacro detachment has been explored focusing on major cross-cutting relationships with the Bembibre detachment and distinct fault planes where only the Pico Sacro detachment-related structures are recognized. The shear zone widths range from some decimetres to metres. Phyllonites represent the ductile expression of the detachment at that stage. It is common to find that frictional fault rocks and ductile fault rocks overlap along the fault plane. Moreover, a quartz vein or dyke several kilometres long appears along the Pico Sacro detachment (Fig. 2). As was pointed out by Gómez Barreiro (2007), the Pico Sacro detachment fault plane acted as a pathway for fluids (Sibson 1990; Bons 2001). Massive input of fluids along the fault may explain the origin of the Pico Sacro quartz vein. Following the Pico Sacro detachment to the east only frictional fault rocks define the fault plane, whereas conjugate and listric normal faults cut across the hanging-wall units, ending at the Pico Sacro detachment fault plane (Figs 1, 2 and 10). These features may suggest that shallower structural levels crop out to the east (Gómez Barreiro 2007).

Low- to very low-ade conditions dominated the late activity of the Pico Sacro detachment. Discrete phyllonitic zones associated with the Bembibre detachment could have nucleated the Pico Sacro detachment, evolving later to a more fragile structure. C' shear bands show a top-to-the-NW sense of shear. Shear sense indicators in cataclasites, including Riedel shears, quartz veins and scarce shear bands in foliated cataclasites, are consistent with that sense of shear (Chester et al. 1985; Evans 1990; Passchier \& Trouw 1996).

Quartz $c$-axis fabrics measured within the Pico Sacro detachment show an almost symmetrical pattern, close to a type I cross girdle (Fig. 9; Lister 1977; Schmid \& Casey 1986). However, density distribution and preferred orientation of subgrain boundaries define a monoclinic pattern. These features are consistent with top-to-the-north shearing and may have developed through a combination of pure and simple shear.

A displacement of roughly $2 \mathrm{~km}$ can be estimated for the Bembibre and Pico Sacro detachments if the Santiago orthomeiss is correlated with comparable felsic orthogneisses eastward, in lower sequence units such as the Lalin unit (Fig. 1). Both extensional suctures were later affected by north south open, subvertical folds, and partially cut by wanscurrent shear zones (Figs 1 and 2). In the study area, a sinistral steeply dipping shear zone defines a high-strain band that deforms Variscan ranites and the lower contact of the basal allochthon. In the footwall to the Pico Sacro detachment, sinistral SC bands developed in granitoids, displaying $\mathrm{L}_{\mathrm{SC}}$ vectors around $150^{\circ} 10^{\circ}$ $N$. Similar structures have been described for all of the allochthonous complexes in the NW Iberian Massif (Iglesias Ponce de León \& Choukroune 1980).

\section{Age of tectonometamorphic events}

The basal allochthon followed a complex tectonic evolution from early burial stages in a subduction zone until the readjus ments leading to crustal equilibration. According to available geochronological data, $37 \mathrm{Ma}$ may be considered an upper bound for the subductive event $\left(\mathbf{D}_{1}\right)$, which probably ended around $365 \mathrm{Ma}$ (Rodríguez et al. 2003; Abati et al. 210). The exhurnation under amphibolite-facies conditions driven by thrusting and recumbent folding directed to the SE $\left(\mathbf{D}_{2}\right)$ is constrained by the Lalin Forcarei thrust activity. This is considered to be the main thrust responsible for the emplacement of the basal allochthon, being active around $340 \mathrm{Ma}$ (Martínez Catalán et al. 1996; Dallmeyer et al. 1997) and later in any case than migmatization in the Agualada unit, dated at $346 \mathrm{Ma}$ (Abati \& Dunning 2002). This stage overlapped that of recumbent folding and resulted in a thickening of the orogenic crust at a regional scale.

The Bembibre Pico Sacro detachment system was active during widespread partial melting and the emplacement of synkinematic ranitoids (Gómez Barreiro et al. 2003, 2007; Martínez Catalán et al. 2009). Its activity may be constrained between $34 \mathrm{Ma}$ and $323 \pm 11$ or $317 \pm 15 \mathrm{Ma}$, the age of crosscutting Variscan granitoids (Bellido et al. 1992; Ortega Cuesta 1998). Unfortunately, no direct dating of $\mathbf{D}_{3}$ deformation fabrics exists to date, but we could find structural counterparts of the Bembibre Pico Sacro detachment system at middle- to lowercrustal levels, where partial melting, related to the gravitational collapse of the orogen, appears to have occurred in neiss domes around $320310 \mathrm{Ma}$ (Díez Montes 2007). A direction roughly parallel to the orogenic rend has been found to be a relevant flow direction in those smuctures (Escuder Viruete et al. 1994; Díez Balda et al. 1995; Díez Montes 2007).

\section{Summary and discussion}

A new tectonometamorphic sequence has been identified in the basal allochthon. A high-grade lens in the uppermost part, with migmatitic paraneisses and granitic orthogneisses, may be correlated with the Agualada unit to the north, on the basis of metamorphic conditions and lithological association (Arenas et al. 1997). The Lamas de Abad unit below shows a clear linkage with the upper sequences of the basal allochthon to the west (Malpica Tui unit), the so-called Ceán unit ('íez Fernández et al. 210; López Carmona et al. 2010). The best-preserved mineral assemblages in the area suggest equilibriurn under high$\boldsymbol{P}$ conditions $\left(\boldsymbol{D}_{1}\right)$, with a later re-equilibration under intermediate- $\boldsymbol{P}$ and lower- $T$ conditions ( $\mathbf{D}_{2}$; greenschist facies) (López Carmona et al. 2010). Structural and kinematic analysis of these rocks suggests that a strong shearing occurred prior to the reequilibration with a general top-to-the-ENE sense of motion.

The Santiago unit occupies the lowermost structural position of the basal units. High-pressure relics $\left(\mathbf{D}_{1}\right)$ appearing as microinclusions within syn- $\mathbf{D}_{2}$ albite porphyroblasts are witnesses of an early episode of subduction. Subsequently, the development of $S_{2}$ could be related to a general top-to-the-SE shearing. - mineral assemblages suggest that an inverted thermal radient did occur in the area, as described by Arenas et al. (1995) in the north. These data are clearly correlated with the first exhumation event identified in other sectors of the basal allochthon, which was accomplished via recumbent folding and thrusting (Arenas et al. 1995; Martínez Catalán et al. 1996; Díez Fernández \& Martínez Catalán 2009).

A later deformation stage $\left(\mathbf{D}_{3}\right)$ resulted in a kinematic change with a persistent top-to-the-NW sense of shear, with the formation of the major Bembibre and Pico Sacro detachments. Previous mineral assemblages appear heterogeneously retroressed, with the development of anastomosed phyllonitic bands across the unit. Field relationships (Figs 2, 4 and 5) show that the Santiago schists on top of the Santiago orthoneiss, Lamas de Abad and Agualada units are lens-shaped and bounded by low-dipping normal faults. This and the absence of the ophiolitic 
allochthon support the subractive character of the detachment system.

Deformation conditions may be inferred from mineral variations and micros uctural evolution. Previous high- $P$ mineral assemblages turned into amphibolite- and reenschist-facies parageneses. Downward in the basal allochthon, a low- $P$ heating event developed, and has been kinematically linked to $\mathbf{D}_{3}$. It seems to be related to the formation of mi matitic domes, which are common at deep levels in the autochthon and Schistose Domain, and associated with the extensional collapse of the orogenic belt (Martínez Catalán et al. 2009). Microstructures and fabric symme provided by structural analysis of the detachment system indicate that a general shear (Hanmer \& Passchier 1991), that is, a combination of simple and pure shear components, with stching parallel to the flow direction, is appropriate to describe the ductile deformation flow during the activity of the detachments.

For the brittle counterpart, deformation mechanisms in the Pico Sacro detachment indicate progressively higher structural levels to the SE. This implies an original dip towards the NE, coincident with the hanging-wall motion (Fig. 10), which reinforces the interpretation of the Pico Sacro detachment as a huge normal fault. Normal listric and conjugate faults occur to the SE of the Pico Sacro detachment, whereas drag folds and reverse faults developed above the Bembibre detachment to the NW. The distributions of these associated structures are similar to those found on mega-slumps (Webb \& Cooper 1988), which, like the Bembibre Pico Sacro detachment system, may have undergone extension in the upper structural levels and shortening at depth (Fig. 10b)

Taking into account isotopic ages and overlapping relationships, we suggest a conceptual model (Fig. 11) in which crustal thickening during $\mathbf{D}_{2}$ was followed by thermal relaxation. This resulted in temperature increase and partial melting during $\mathbf{D}_{3}$, which facilitated the ductile flow that accomplished gravitational extension in the lower to middle crust (Vanderhaege \& Teyssier 2001; Gómez Barreiro et al. 2007; Martínez Catalán et al. 2009). The mechanisms responsible for ransferring this flow to the upper crust are often obscure, but in our case, the Bembibre Pico Sacro system seems to be the upper crustal expression of the late orogenic extensional collapse. The detachments would act as a rheological boundary between the upper part of the orogenic pile, here represented by the ophiolitic and upper allochthons, which behaved rigidly, and the ductile middle crust (Fig. 11).

In spite of cross-cutting relationships between the Bembibre and Pico Sacro detachments (Fig. 10a), they seem to represent a continuous process, which evolved from medium- to low-grade and, finally, to very low-grade conditions. Extensional shear zones preferentially concentrate in the upper part of the structural sequence of the basal allochthon, where a previous, top-to-theENE thrust-related high-s rain shear zone existed. Its presence may have favoured the nucleation of the Bembibre detachment, which would have reactivated older fabrics. Moreover, the deformation regime in the $\mathbf{D}_{3}$ detachment system also evolved, as docurnented by the overprinting of dominant ductile (Bembibre detachment) to brittle ductile or brittle fault rocks (Pico Sacro detachment).

The basal allochthon concentrated important displacements of the allochthonous complexes during the Variscan orogeny. Although renewal of pre-existing features, such as lithological contacts and/or shear zones, is derived from our data, precise dating of each deformation stage would provide the clues to differentiate rue reactivation from a continuous event (Butler et al. 1997; Miller et al. 2001). In any case, our data support a strong influence of the pre-existing tectonothermal architecture on the deformational response of the basal allochthon. It is proposed that the basal allochthon may be considered a crustal volume where tectonic reworking was concentrated for at least $50 \mathrm{Ma}$.

\section{Conclusions}

The structural and kinematic analysis carried out in the basal allochthon of the southwestern part of the Ordenes Complex has resulted in the identification of the Santiago, Lamas de Abad and

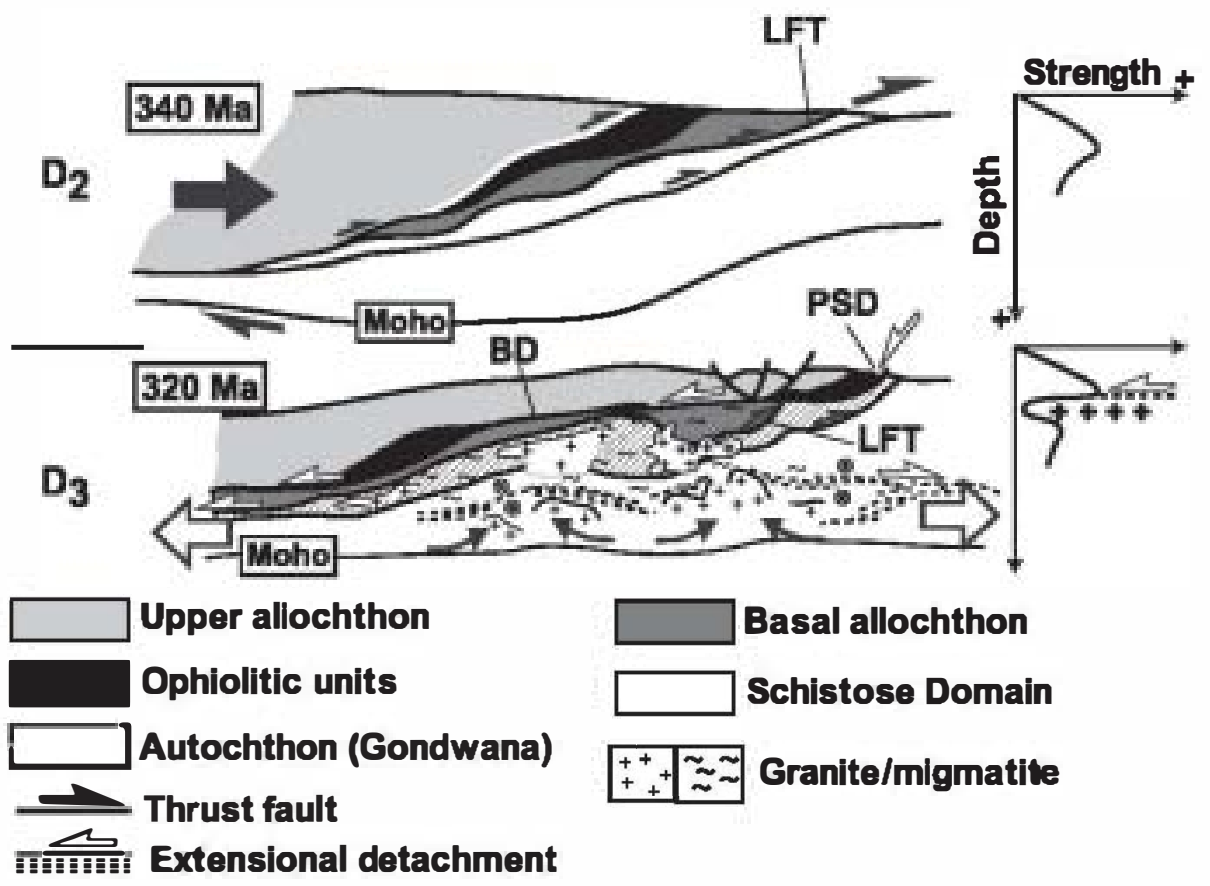

Fig. 11. Conceptual model (not to scale) of the exhumation of the basal allochthon in the area. 2 stage results in the exhumation of the basal units through a combination of thrusting and recumbent folding. Early stages may have developed under high- $\boldsymbol{P}$ conditions. The Lalin-Forcarei thrust (LFT) represents the most significant thrust fault with an eastward kinematics. Later, $\mathbf{D}_{2}$ shortening associated with the underthrusting of Gondwana basement developed an out-of-sequence thrust system that barely dismembered the basal allochthon (Gómez Barreiro et al. 2007; Martínez Catalán et al. 2009). After $\mathbf{D}_{2}$ thickening, thermal relaxation led to widespread melting of the lower and midale crust, during $\mathbf{D}_{3}$. The orogenic pile became mechanically unstable, resulting in an extensional collapse. Whereas domes and viscous flow developed at depth, extensional detachments nucleated at the base of the rigid upper crustal segments. The Rembibre and Pico Sacro detachments (BD, PSD) are representative of this evolution. 
Agualada units, of which the last two have not been described before. The tectonometamorphic evolution that we found led us to assin these units to two distinct parts of the basal allochthon: the upper sequence (Lamas de Abad unit) and the lower sequence (Santiago and Agualada units). An episode of thrusting related to a collisional stage led to the development of an inverted metamorphic gradient, and the duplication of lower sequence units. A similar relationship could be extended to the north in the Ordenes Complex.

Three main tectonic phases are responsible for the configuration of the basal allochthon. The first was a high-pressure event related to the subduction of the whole ensemble, $\mathbf{D}_{1}$, the late stages of which seem to be preserved in the Lamas de Abad unit, where a top-to-the-ENE sense of shear has been recognized. This kinematics is consistent with a subduction component to the west in present coordinates previously inferred from the distribution of high- $\boldsymbol{P}$ metamorphic zoning. A second, amphibolite-facies event with top-to-the-SE kinematics and related to the regional exhurnation of the units through thrusting and recumbent folding, $\mathbf{D}_{2}$, is widely distributed in the three units. The third phase, $\mathbf{D}_{3}$, occurred under retrossive amphibolite- to greenschist-facies conditions, and resulted in the development of the Bembibre Pico Sacro detachment system, a regional-scale extensional framework with deformation discibuted heterogeneously and top-to-the-NW kinematics.

The structural position and fault-rock evolution suggest that the Bembibre Pico Sacro system partially rejuvenated pre-existing shear zones, whose weakness may have favoured the nucleation of the detachments by reactivation of older fabrics. During this phase, syntectonic low- $\boldsymbol{P}$ and high- to medium- $T$ assemblages formed at the bottom of the basal allochthon. Later in $\mathbf{D}_{3}$, the Pico Sacro detachment cut across the Bembibre detachment under reenschist-facies conditions and a viscous to frictional regime. According to the cross-cutting relationships and regional geology, the Bembibre Pico Sacro system is coeval with late orogenic extensional collapse and widespread matism, and represents its upper-crustal expression. The detachments correlate with mid- and lower-crustal flow and the development of neiss domes at depth.

Therefore, the basal allochthon analysed here can be considered as an orogenically reworked crustal ensemble representing a rheological boundary layer between the more rigid upper allochthon above and the more viscous Schistose Domain and autochthon below.

This work is dedicated to the memory of F. Díaz García, a remarkable scientist and an outstanding person. His mentorship, friendship and support will be greatly missed. Funding was provided by the Dirección General de Programas y Transferencia del Conocimiento (Spanish Minis of Science and Innovation), research project CGL2007-65338C2-01 and -02/BTE. J.G.B. was supported by MEC-Juan de la Cierva Postdoctoral contract. We are grateful to S. Smith, J. von Raumer and an anonymous referee for thorough and constructive reviews, and to $\mathrm{K}$. McCaffrey for the editorial work.

\section{References}

Abarr, J. \& DunNING, G.R. 2002. Edad U-Pb en monacitas y rutilos de los paragneises de la Unidad de Agualada (Complejo de Órdenes, NW del Macizo Ibérico). Geogaceta, 32, 95-98.

abati, J., arrnas, R, Marmínbz Catalán, J.R. \& Díaz García, F. 2003. Anticlockwise $\boldsymbol{P}-T$ path of granulites fiom the Monte Castelo Gabbro (Órdenes Complex, NW Spain). Journal of Petrology, 44, 305-327.

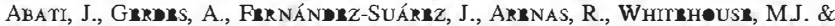
Dí Z FRRNÁN@Z, R. 2010. Magmatism and early-Variscan continental subduction in the northern Gondwana margin recorded in zircons fiom the basal units of Galicia, NW Spain. Geological Sociery of Americ Bulletin, 122, 219-235

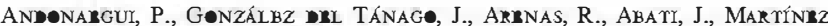
Catalan, J.R., Prinaøo, M. \& Díaz García, F. 2002. Tectonic setting of the Monte Castelo gabbro (Ordenes Complex, northwestern Iberian Massif) Evidence for an arc-related terrane in the hanging wall to the Variscan suture In: Mar mínbz CaTalán, J.R., Ha TChrk, R.D., JR, ARrnas, R. \& Díaz García, F. (eds) Variscan-Appalachian Dnamics: the Building of the Late Paleozic Basement. Geological Society of America, Special Papers, 364, $37-56$.

armas, R., Rubr Pascual, FJ., Díaz Garuia, F. \& Marrínez Caralán, J.R 1995. High-pressure micro-inclusions and development of an inverted metamorphic gradient in the Santiago Schists (Ordenes Complex, NW Iberian Massif, Spain): evidence of subduction and syn-collisional decompression. Journal of Metamorphic Geology, 13, 141-164.

arrnas, R., abart, J., Marrínez Caralán, J.R, Diaz Garéa, F. \& Rubie PAscual, FJ. 1997. $\boldsymbol{P}-T$ evolution of eclogites fiom the Agualada Unit (Ordenes Complex, NW Iberian Massif, Spain): Implications for crustal subduction. Lithøs, 40, 221-242.

arrnas, R., Mar mínez Caralán, J.R., Sánchez Mar mínbz, S., er al. 2007 Paleozoic ophiolites in the Variscan suture of Galicia (northwest Spain) distribution, characteristics and meaning. In: HA TCHRk, RD., Jk, CARLS N, M.P., MCBRme, J.H. \& MARTÍNBZ CATALÁN, J.R. (eds) 4-D Framewerk • Continental Crust. Geological Society of America, Memoirs, 200, 425-444, doi: $10.1130 / 2007.1200(22)$

Brulme, F., Brandu, JL., LASALA, M. \& Rryes, J. 1992. Consideraciones petrológicas y cronológicas sobre las rocas graníticas hercínicas de Galicia Cuadernos do Laboratorio Xeolóxico de Laxe, 17, 241-261.

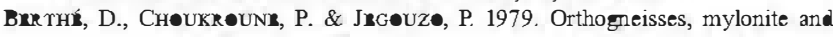
non coaxial deformation of granites: the example of the South Armorican Shear Zone. Journal of Structural Geology, 1, 31-42.

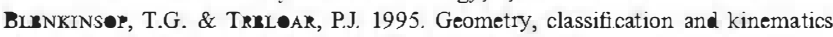
of $\mathrm{S}-\mathrm{C}$ and $\mathrm{S}-\mathrm{C}$ ' fabrics in the Mushandike area, Zimbabwe. Journal of Structural Geology, 17, 397-408

B॰Ns, P. 2001. The formation of large quartz veins by rapid ascent of fiuids in mobile hydrofiactures. Tectøn॰physics, 336, 1-17.

Bøuchiz, J.L. 1978. Preferred orientation of quartz $<$ > axes in some tectonites kinematic inferences. Tecton physics, 49, 25-30.

BurLRk, R.W.H., HøL reactivation in continental defornation. Joumal of the Geological Sociery, London, 154, 69-71.

CASMÑRmaS, P. 2005. Origen y evolución tectonotennal de las unidades de O Pin y Cariñø (Complejos Alóctonos de Galicia). Laboratorio Xeolóxico de Iaxe, Serie Nova Terra, 28

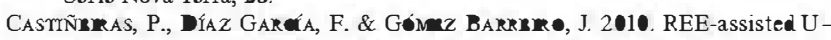
$\mathrm{Pb}$ zircon age (SHRIMP) of an anatectic granodiorite: Constraints on the evolution of the A Silva granodiorite, Iberian Allochthonous Complexes. Lith॰s, doi:10.1016/j.lithos.20101.013.

CYmstik, F.M., Ferman, M. \& L@GAN, J.M. 1985. Foliated cataclasites Tecton॰physics, 111, 134-146.

Dallmeyre, R.D., Mar mínez CaTalán, J.R., ARenas, R, er al. 1997 Diachronous Variscan tectonothermal activity in the NW Iberian Massif: Evidence from ${ }^{40} \mathrm{Ar} /{ }^{39} \mathrm{Ar}$ ating of regional fabrics. Tecton physics, 277, $307-337$.

-íaz García, F. 1990. La geologia del sector occidental del Complejø de Ordenes (Cordiller Hercinica, NW de España). Laboratorio Xeolóxico de Laxe, Serie Nova Terra, 3.

Díaz García, F., armas, R., Martínez CaTalán, J.R., Genzálnz mel TÁNAG•, J. \& DunNInG, G. 1999. Tectonic evolution of the Careón ophiolite (Northwest Spain): a renunant of oceanic lithosphere in the Variscan belt. Journal of Geology, 107, 587-605.

Dí z BaL a, M.A., Marrínz CaTalân, J.R \& Ayarza, P. 1995. Syn-collisional extensional collapse parallel to the orogenic trend in a domain of steep tectonics: the Salamanca detachment zone (Central Iberian Zone, Spain). Journal of Structural Geology, 17, 163-182.

DÉ Z FrRnándrz, R. \& Marrínez CaTalán, J.R. 2009. 3D analysis of an Ordovician igneous ensemble: A complex magmatic structure hidden in a polydeformed allochthonous Variscan Unit. Journal of Structural Geology, 31, 222-236.

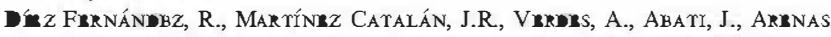
R. \& FRRNÁNDZZ-SUÁRRZ, J. 2010. U-Pb ages of detrital zircons from the Basal allochthonous units of NW Iberia: Provenance and paleoposition on the northem margin of Gondwana during the Neoproterozoic and Paleozoic. Gondwan Research, doi:10.1016/j.gr.2009.12.006.

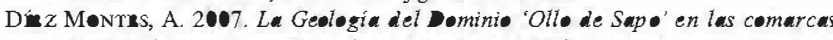
de Sanabria y Terra do Bolo. Iaboratorio Xeolóxico de Laxe, Serie Nova Terra, 34.

ESCUmer Vmurtz, J., ARrnas, R. \& MARTínez CATALAN, JR. 1994. Tectonother- 
mal evolution associated with Variscan crustal extension in the Tormes Gneiss Dome (NW Salamanca, Iberian Massif, Spain). Tectøn ploysics, 238, 117-138.

Evans, J.P. 1990. Textures, deformation mechanisms and the role of fluids in the cataclastic deformation of granite rocks. In: KNms, R.J. \& RUrTrk, E.H (eds) Defonnation Mechanisms, Rheology and Tectonics. Geological Society, London, Special Publications, 54, 29-39.

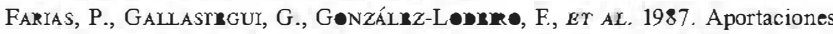
al conocimiento de la litoestratigrafía y estructura de Galicia Central. Memórias da Faculdade de Cièncias, Universidade do Porto, 1, 411-431

Gr. InARGUerr, I. \& ORTrGA Gronis, E. 1985. Petrology, structure and geotectonic implications of glaucophane-bearing eclogites and related rocks from the Malpica-Tuy (MT) Unit, Galicia, Northwest Spain. Chemical Geology, 50, 145-162.

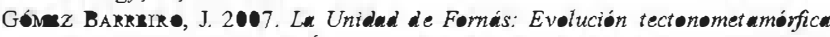
del SO del Complejø de Órdenes. Laboratorio Xeolóxico de Laxe, Serie Nova Terra, 32

Gomez Barkerre, J., Martínez CaTalán, J.R., Arenas, R. \& Díaz Garéa, F. 2002. Caracterización cinemática del contacto inferior de la Unidad de Fornás (Comple jo de Órdenes, NW del Macizo Ibérico). Studia Geologic Salmanticensia, 38, 105-127.

Gómez Bakrmire, J., Marrínez CaYalán, JR. \& ARrnas, R. 2003. Reactivation of a major tectonic boundary: preservation of crystallographic fabrics. In Defonnation Mechanisms, Rheology and Tectonics. St. Malo (France), Abstracts, 65 .

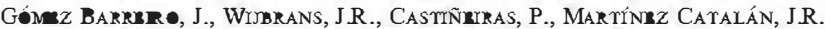
ARrnas, R., DÍAZ García, F. \& Alarr, J. 2006. ${ }^{40} \mathrm{Ar} /{ }^{39} \mathrm{Ar}$ laserprobe dating of mylonitic fabrics in a polyorogenic terrane of the NW Iberia. Joumal the Geological Society, London, 163, 61-73.

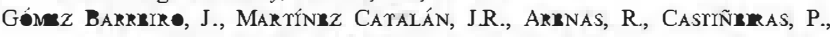
Amari, J., faz Garua, F. \& Wmorans, J.R. 2007. Tectonic evolution of the upper allochthon of the Ordenes Complex (northwestern Iberian Massif) structural constraints to a polyorogenic peri-Gondwanan terrane. In: LnNNe MANN, U., NANe, R.D., Krafr, P. \& ZULAUf, G. (eds) The Evolution of the Rheic Ocean: from Avalonian-Cadomian Active Margin to AlleghenianVariscan Collision. Geological Society of America, Special Papers, 423, 315 332.

Gomez Barkerke, J., Marrínez Caralán, J.R., Priek, D., er al. 2010. Fabric development in a middle Devonian intraoceanic subduction regime: the Careón ophiolite (northwest Spain). Joumal of Geology, 118, 163-186.

HANMER, S. \& PASSCHmR, C.W. 1991. Shear Sense Indicators: a Review Geological Survey of Canada Papers, 90.

Høuswer TH, R.E., Burunk, C.A. \& Røerers, A.M. 1997. The recognition of reactivation during continental deformation. Joumal of the Geological Sociery, London, 154, 73-78

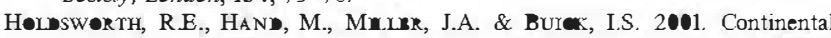
reactivation and reworking: an introduction. In: Mr.urk, J.A., Hel@swerm, R.E., BurCK, I.S. \& HAN, M. (eds) Continental Reactivation and Reworking. Geological Society, London, Special Publications, 184, 1-12.

Høusman, G.A. \& MølNAR, P. 2001. Mechanisms of lithospheric renewal associated with continental orogeny. In: MrLurk, J.A., HøL SW $\bullet$ RH, RE. BurCK, I.S. \& HAND, M. (eds) Continental Reactivation and Reworking. Geological Society, London, Special Publications, 184, 13-37.

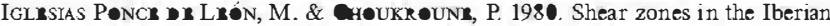
anc. Journal of Structural Geology, 2, 63-68.

KNer, R.J. \& LAW, R.D. 1987. The influence of crystallographic orientation and grain boundary migration on microstructural and textural development in a S-C mylonite. Tectøn॰ physics, 135, 155-169.

Kurz, W., FrIrZ, H., TrNCZRk, V. \& UnzeG, W. 2002. Tectonometamorphic evolution of the Koraltn Complex (Eastern Alps): constraints from microstructures and textures of the 'Plattengneis' shear zone. Journal of Structural Geology, 24, 1957-1970.

LAW, R.D., MrLnk, EL., Lrrrre, T.A. \& Lne, J. 1994. Extensional origin of ductile fabrics in the Schist Belt, Central Brooks Range, Alaska-II Microstructural and petrofabric evidence. Journal of Structural Geology, 16 919-940

LisTRk, G.S. 1977. Discussion: crossed-girdle c-axis fabrics in uartzites plastically deformed by plane strain and progressive simple shear. Tectonophysics, 39, 51-54

LISTRk, G.S. \& SNøKR, A.W. 1984. S-C mylonites. Journal of Structural Geology, 6, 617-638

Listnk, G.S., PArmen, M.S. \& Høns, B.E. 1978. The simulation of fabric development in plastic deformation and its application to quartzite: the model. Tectonøphysics, 45, 107-158

Lóprz CARMøna, A., AMATI, J. \& Reche, J. 2010. Petrologic modeling of chloritoid-glaucophane schists from the NW Iberian Massif. Gondwana Research, 17, 377-391.

Marrínrz Catalán, J.R., Armas, R., Díaz García, F., Rubre Pascual, F.J., Amarr, J. \& MareứneZ, J. 1996. Variscan exhumation of a subducted
Paleozoic continental margin: The basal units of the Ordenes Complex, Galicia, NW Spain. Tectonics, 15, 106-121.

Marrínzz Caralán, J.R., Akrnas, R., díaz Garéa, F. \& Amari, J. 1997 Variscan accretionary complex of northwest Iberia: Terrane correlation and succession of tectonothermal events. Geology, 25, 1103-1106.

Marrínez Caralán, J.R., Díaz García, F., ARmas, R., EY aL. 2002. Thrust and detachment systems in the Ordenes Complex (northwestern Spain): Implications for the Variscan-Appalachian geodynamics. In: MAR MÍnez CATALÁN,

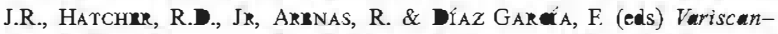
Appalachian Dynamics: the Building of the Late Paleozoic Basement. Geological Society of America, Special Papers, 364, 163-182.

Martínez Caralán, J.R., Arrnas, R., ABari, J, eT aL. 2009. A rootless suture and the loss of the roots of a mountain chain: the Variscan belt of NW Iberia. Comptes Rendus Géoscience, 341, 114-126.

Mulre, J.A., Hol sworma, R.E., BuICK, I.S. \& HAN!, M. (eds) 2001 Continental Reactivation and Rewerking. Geological Society, London, Special Publications, 184

Nen, E.A. \& Housman, G.A. 1997. Geodynamics of the Tarim Basin and the Tien Shan in central Asia. Tectonics, 16, 571-584.

OKunarka, T., Tareshria, T., Hara, I. \& AN@e, J. 1995. A new estimate of the conditions for transition from basal to prism [c] slip in naturally deformed quartz. Tecton physics, 250, 31-46.

OrTrGA CURSTA, L.A. 1998. Estudi॰ petrogenétic del granit॰ sincinemátic de dos micus de $A$ Espenuc (A Coruña). Laboratorio Xeolóxico de Laxe, Serie Nova Terra, 14

PAsscrmek, C.W. \& Tkouw, R.A.J. 1996. Microtectonics. Springer, Berlin.

PAsscrimk, C.W. \& WrrmaMs, P.R. 1996. Conflicting shear sense indicators in shear zones; the problem of non-ideal sections. Joumal of Structural Geology, $18,1281-1284$

Pin, C., Papurtre, J.L., Santes Zalmurgur, J.F. \& Gil Imarguemi, J.I. 2002 Early Devonian supra-subduction zone ophiolite related to incipient collisional processes in the Western Variscan Belt: The Sierra de Careón unit, Ordenes Complex, Galicia. In: Marrínez Caralán, J.R., Harcrenk, R.D., JR, ARRNAS, R. \& DÍAZ GARCíA, F. (eds) Variscan-Appalachian Dnamics the Building of the Late Paleozic Basement. Geological Society of America, Special Papers, 364, 57-71

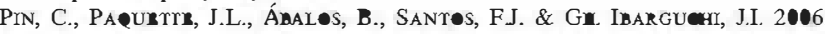
Composite origin of an early Variscan transported suture: Ophiolitic units of the Morais Nappe Complex (north Portugal). Tectonics, 25, TC501.

RAMSAY, J.G. \& HUner, M.I. 1987. The Techniques of Modern Structural Geology. Volume 2: Folds and Fractures. Academic Press, London, 309-700.

Rinerre, A., Prerema, E. \& Dras, R. 1990. Central-Iberian Zone. Allochthonous Sequences. Structure in the Northwest of the Iberian Peninsula. In: Dallmerno, R.D. \& Marrínez García, E. (eds) Pre-Mesozoic Geology of Iberia. Springer, Berlin, 22-236

Roprigurz, J., Cosca, M.A., Gir Inarguchi, J.I. \& Dalumeyme, R.D. 2003. Strain partitioning and preservation of ${ }^{4} \mathrm{Ar} /{ }^{39} \mathrm{Ar}$ ages during Variscan exhumation of a subducted crust (Malpica-Tui complex, NW Spain). Lithos, 70, 111-139

Rønkigurz, R., Marces, A. \& Farias, P. 2004. Palynological data on the age of the metasediments of the Parautochthonous Thrust Sheet in the Cabo Ortegal area (Galicia, NW Spain). Neues Jahrbuch für Geologie und Palciontologie, $10,437-447$.

Roprígurz ALIRk, J. 2005. Recristalización y defonnación de litologias supracorticales sometidas a metamorfism• de alta presión (Complej• de Malpica-Tui, NO del Maciz• Ibéric ). Laboratorio Xeolóxico de Laxe, Nova Terra, 29.

Röller, K. \& TRAPMANN, C.A. 2008. Stereo32 (v.1.0.1). World Wide Web Address: http://www.ruhr-uni-bochumde/hardrock/Stereo32.h ml

Run Pascual, FJ., arenas, R., Díaz García, F., Mar rínez Caralán, J.R. \& ABATr, J. 2002. Eclogites and eclogite-amphibolites from the Santiago Unit (Ordenes Complex, NW Iberian Massif, Spain): a case study of contrasting high-pressure metabasites in a context of crustal subduction. In: Mar ríneZ CaTalán, J.R., HaTchrk, R.D., Jk, ARrnas, R. \& Díaz García, F. (eds) Variscan-Appalachian Bnamics: the Building of the Late Paleozoic Basement. Geological Society of America, Special Papers, 364, 105-124.

Sánchez Marrínrz, S., ARrnas, R., Anmonargur, P., Marrínrz CaTalán, J.R. \& PaAR, J.A. 2007a. Geochemistry of two associated ophiolites from the Cabo Ortegal complex (Variscan belt of northwest Spain). In: Harcrenk, R.D., Jk, CARLs@N, M.P., MCBrrme, J.H. \& Marrínrz CaTalán, J.R. (eds) 4-Drumework of Continental Crust. Geological Society of America, Memoirs, 200, 445-467.

Sánchez Marmínzz, S., Arrnas, R, díaz García, F., Maruínrz Catalán, J.R., Gomez-Barkrme, J. \& Prare, J.A. 2007b. Careón Ophiolite, NW Spain: Suprasubduction zone setting for the youngest Rheic Ocean floor. Geology, 35, 53-56

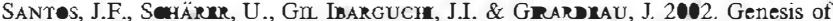
pyroxenite-rich peridotite at Cabo Ortegal (NW Spain): geochemical and $\mathrm{Pb}-$ $\mathrm{Sr}-\mathrm{N}$ isotope data. Joumal of Petrulogy, 43, 17-43. 
Serme, S.M. \& CASPY, M. 1986. Complete fabric analysis of some conunonly observed quartz c-axis patterns. In: HøBBs, B.E. \& Hrare, H.C. (eds) Mineral and Rock Deformation: Laboratory Studies. The Paterson Volume. American Geophysical Union, Geophysical Monograph, 36, 263-286.

Sws $\bullet$ R.H 1990. Conditions of fault-valve behaviour. In: KNw2, R.J. \& Rurrnk, E.H. (eds) Defonnation Mechanisms, Rheology and Tectonics. Geological Society, London, Special Publications, 54, 15-28.

Smesen, C. \& Schner, S. 1983. An evaluation of criteria to deduce the sense of movement in sheared rocks. Geological Sociery of Americ Bulletin, 94, 1281-1288.

Tøy, V.G., Pkrok, D.J. \& Nokers, R.J. 2008. Quartz fabrics in the Alpine Fault mylonites: Infiuence of pre-existing preferred orientations on fabric development uring progressive uplift. Joumal of Structural Geology, 30, 602-621.

Thépme, L., Dourran, J.C. \& PAQuer, J. 1980. Subgrain boundaries in quartz: theoretical analysis and microscopic observations. Physics and Chemistry of
Minerals, 5, 201-218

Valverme-Va unke, P., Marces, A., Fakras, P. \& Gallasrigur, G. 2005. U-Pb dating of Ordovician felsic volcanism in the Schistose Domain of the Galicia-Trás-os-Montes Zone near Cabo Ortegal (NW Spain). Geológic Acta, 3, 27-37.

VANDrRHAar, O. \& Tryssme, C. 2001. Crustal-scale rheological transitions during late-orogenic collapse. Tecton॰physics, 335, 211-228.

VAN ZUUReN, A. 1969. Structural petrology of an area near Santiago de Compostela (NW Spain). Leidse Geologische Mededelingen, 45, 1-71.

Wrek, B.C. \& Coopre, A.H. 1988. Slump folds and gravity slide structures in a Lower Paleozoic marginal basin sequence (the Skiddaw Group), NW England. Joumal of Structural Geology, 10, 463-472.

Whrerrek, J. 1987. The determination of true shear senses from the defiection of passive markers in shear zones. Journal of the Geological Society, London, $144,73-77$. 